Southern Illinois University Edwardsville

SPARK

SIUE Faculty Research, Scholarship, and Creative Activity

Spring 3-29-2017

\title{
Synthesis, Structural Characterization and Catalytic Activity of Indenyl Complexes of Ruthenium Bearing Fluorinated Phosphine Ligands
}

\author{
Matthew J. Stark \\ University of Missouri-Saint Louis \\ Michael J. Shaw \\ Southern Illinois University at Edwardsville \\ Arghavan Fadamin \\ Southern Illinois University Edwardsville \\ Nigam P. Rath \\ University of Missouri-Saint Louis \\ Eike B. Bauer \\ University of Missouri-Saint Louis
}

Follow this and additional works at: https://spark.siue.edu/siue_fac

Part of the Inorganic Chemistry Commons

\section{Recommended Citation}

Stark, Matthew J.; Shaw, Michael J.; Fadamin, Arghavan; Rath, Nigam P.; and Bauer, Eike B., "Synthesis, Structural Characterization and Catalytic Activity of Indenyl Complexes of Ruthenium Bearing Fluorinated Phosphine Ligands" (2017). SIUE Faculty Research, Scholarship, and Creative Activity. 119.

https://spark.siue.edu/siue_fac/119

This Article is brought to you for free and open access by SPARK. It has been accepted for inclusion in SIUE Faculty Research, Scholarship, and Creative Activity by an authorized administrator of SPARK. For more information, please contact magrase@siue.edu. 


\section{Synthesis, Structural Characterization and Catalytic}

\section{Activity of Indenyl Complexes of Ruthenium Bearing}

\section{Fluorinated Phosphine Ligands}

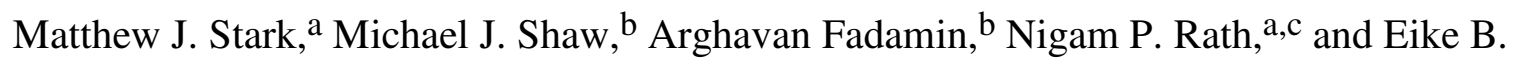
Bauer $^{\mathrm{a}, *}$

Dedicated to Professor John A. Gladysz on the occasion of his $65^{\text {th }}$ birthday.

a University of Missouri - St. Louis, Department of Chemistry and Biochemistry, One University Boulevard, St. Louis, MO 63121, USA.

b Southern Illinois University Edwardsville, Department of Chemistry, Edwardsville, IL 62025, USA.

${ }^{\mathrm{c}}$ Center for Nanoscience, University of Missouri - St. Louis, One University Boulevard, St. Louis, MO 63121, USA.

bauere@umsl.edu

To be submitted to the Journal of Organometallic Chemistry

Keywords: electronic tuning, X-ray, cyclic voltammetry, propargylic alcohols 


\begin{abstract}
The synthesis, characterization and catalytic activity of new ruthenium complexes of fluorinated triarylphosphines is described. The new ruthenium complexes $\left[\mathrm{RuCl}(\mathrm{ind})\left(\mathrm{PPh}_{3}\right)\{\mathrm{P}(p\right.$ $\left.\left.\left.\mathrm{C}_{6} \mathrm{H}_{4} \mathrm{CF}_{3}\right)_{3}\right\}\right]$ and $\left[\mathrm{RuCl}(\mathrm{ind})\left(\mathrm{PPh}_{3}\right)\left\{\mathrm{P}\left(3,5-\mathrm{C}_{6} \mathrm{H}_{3}\left(\mathrm{CF}_{3}\right)_{2}\right)_{3}\right\}\right]$ were synthesized in $57 \%$ and $24 \%$ isolated yield, respectively, by thermal ligand exchange of $\left[\mathrm{RuCl}(\mathrm{ind})\left(\mathrm{PPh}_{3}\right)_{2}\right]$, where ind $=$ indenyl ligand $\eta^{5}-\mathrm{C}_{9} \mathrm{H}_{7}{ }^{-}$. The electronic and steric properties of the new complexes were studied through analysis of the X-ray structures and through cyclic voltammetry. The new complexes $\left[\mathrm{RuCl}(\right.$ ind $\left.)\left(\mathrm{PPh}_{3}\right)\left\{\mathrm{P}\left(p-\mathrm{C}_{6} \mathrm{H}_{4} \mathrm{CF}_{3}\right)_{3}\right\}\right]$ and $\left[\mathrm{RuCl}(\mathrm{ind})\left(\mathrm{PPh}_{3}\right)\left\{\mathrm{P}\left(3,5-\mathrm{C}_{6} \mathrm{H}_{3}\left(\mathrm{CF}_{3}\right)_{2}\right)_{3}\right\}\right]$ and the known complex $\left.\left[\mathrm{RuCl}(\mathrm{ind})\left(\mathrm{PPh}_{3}\right)_{2}\right\}\right]$ differed only slightly in their steric properties, as seen from comparison of bond lengths and angles associated with the ruthenium center. As determined by cyclic voltammetry, the redox potentials of $\left[\mathrm{RuCl}(\mathrm{ind})\left(\mathrm{PPh}_{3}\right)\left\{\mathrm{P}\left(p-\mathrm{C}_{6} \mathrm{H}_{4} \mathrm{CF}_{3}\right)_{3}\right\}\right]$ and $\left[\mathrm{RuCl}(\mathrm{ind})\left(\mathrm{PPh}_{3}\right)\left\{\mathrm{P}\left(3,5-\mathrm{C}_{6} \mathrm{H}_{3}\left(\mathrm{CF}_{3}\right)_{2}\right)_{3}\right\}\right]$ are +0.173 and $+0.370 \mathrm{~V}$ vs. $\mathrm{Cp}_{2} \mathrm{Fe}^{0 /+}$, respectively, which are substantially higher than that of $\left[\mathrm{RuCl}(\mathrm{ind})\left(\mathrm{PPh}_{3}\right)_{2}\right](-0.023 \mathrm{~V})$. After activation through chloride abstraction, the new complexes are catalytically active in the etherification of propargylic alcohols (8 to $24 \mathrm{~h}$ at $90{ }^{\circ} \mathrm{C}$ in toluene, $1-2$ mol\% catalyst loading, $29-61 \%$ isolated yields). As demonstrated by a comparative study for a test reaction, the three precursor complexes [RuCl(ind) $\left.\left(\mathrm{PPh}_{3}\right)\left\{\mathrm{P}\left(p-\mathrm{C}_{6} \mathrm{H}_{4} \mathrm{CF}_{3}\right)_{3}\right\}\right],\left[\mathrm{RuCl}(\right.$ ind $\left.)\left(\mathrm{PPh}_{3}\right)\left\{\mathrm{P}\left(3,5-\mathrm{C}_{6} \mathrm{H}_{3}\left(\mathrm{CF}_{3}\right)_{2}\right)_{3}\right\}\right]$ and $\left.\left[\mathrm{RuCl}(\mathrm{ind})\left(\mathrm{PPh}_{3}\right)_{2}\right\}\right]$ differed only slightly in catalytic activity.
\end{abstract}

\title{
1. Introduction
}


Transition metal complexes of ruthenium are widely utilized in catalysis and other areas of chemical research [1]. A large number of ruthenium complexes have been described in the literature, and they have found applications as catalysts in reactions such as oxidations [2], olefin metathesis [3], and a number of carbon-carbon, carbon-nitrogen and carbon-oxygen bond forming reactions [4]. The quest for sterically and electronically tuned ruthenium complexes is ongoing to satisfy the growing need of such complexes in the area of medicinal chemistry [5] and the development of optical devices [6].

The known [7] ruthenium indenyl complex $\left[\mathrm{RuCl}(\mathrm{ind})\left(\mathrm{PPh}_{3}\right)_{2}\right]\left(\right.$ ind $\left.=\eta^{5}-\mathrm{C}_{9} \mathrm{H}_{7}^{-}\right)$has previously been utilized as a starting material for organometallic syntheses [8] and other ruthenium indenyl complexes are frequently applied in synthesis [9] and catalysis [10]. The increased reactivity of indenyl complexes has been ascribed to the so called "indenyl effect" [11]. As part of our long standing research program directed towards the catalytic activation of propargylic alcohols [12], we identified ruthenium indenyl complexes as valuable starting materials not only for the synthesis of ruthenium complexes [12a,c,f], but also as potential catalysts in nucleophilic substitution reactions [12a,c]. However, a serious drawback of these catalyst systems are the high reaction temperatures of 80 to $90{ }^{\circ} \mathrm{C}$ required for transformations. The high reaction temperatures are undesirable because of the energy required and the difficulties of obtaining high enantiomeric excess values under such conditions in addition to rearrangements that often occur as side reactions, lowering the yield of the desired product. We hypothesized that electron-withdrawing groups on the ruthenium center might increase its reactivity, as these groups might facilitate the nucleophilic attack on (potential) carbocation intermediates. Our previous electronic tuning efforts utilizing electron-withdrawing ligands resulted in the synthesis of the tris $\left(N\right.$-pyrrolyl)phosphine complex $\left[\mathrm{RuCl}(\mathrm{ind})\left(\mathrm{PPh}_{3}\right)\left\{\mathrm{P}(\mathrm{pyr})_{3}\right\}\right]$ 
(pyr $=N$-pyrrolyl, see Figure 1), which catalytically activated propargylic alcohols, albeit still at reaction temperatures around $85^{\circ} \mathrm{C}[12 \mathrm{a}]$.

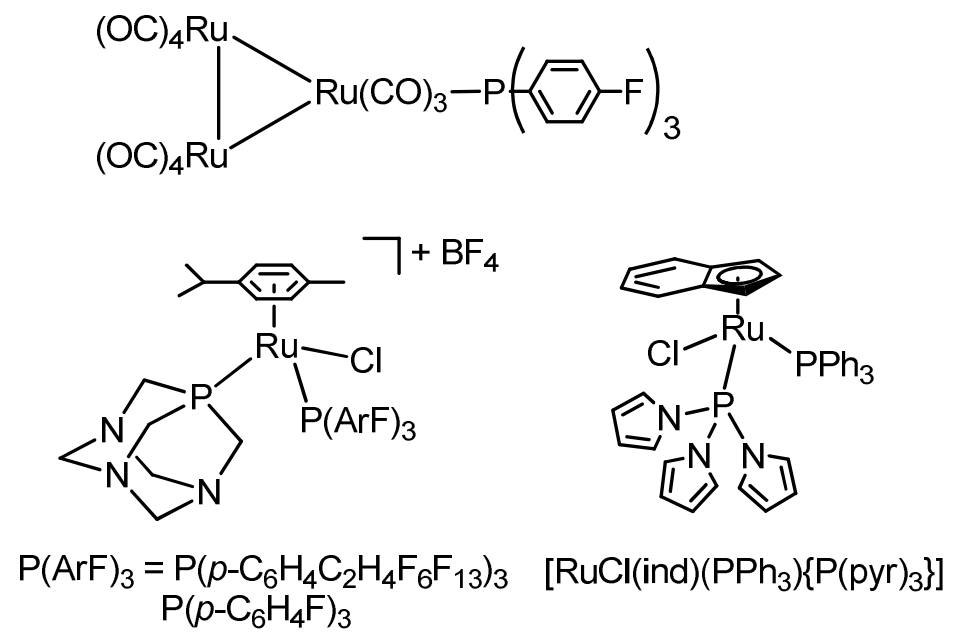

\section{Figure 1. Representative electronically tuned ruthenium complexes.}

Fluorinated phosphine ligands have previously been utilized to electronically tune ruthenium complexes, representative examples are shown in Figure 1 [13]. Ruthenium complexes bearing fluorinated phosphine ligands have been applied in catalysis [14] and also exhibited anticancer activity [15].Fluorinated phosphines have also been employed in the synthesis of metal complexes to be employed for fluorous biphasic catalysis [16]; for example, Gladysz published fluorous analogs of Grubbs' second-generation catalyst to be employed in ring-opening metathesis polymerization [17]. In context of our own research, we hypothesized that ruthenium indenyl complexes bearing electron-withdrawing, fluorinated phosphine ligands show, due to their increased Lewis acidity, enhanced catalytic activity in the transformation of propargylic alcohols.

Herein, we describe the synthesis and characterization of the ruthenium complexes $\left[\mathrm{RuCl}(\mathrm{ind})\left(\mathrm{PPh}_{3}\right)\left\{\mathrm{P}\left(p-\mathrm{C}_{6} \mathrm{H}_{4} \mathrm{CF}_{3}\right)_{3}\right\}\right]$ and $\left[\mathrm{RuCl}(\mathrm{ind})\left(\mathrm{PPh}_{3}\right)\left\{\mathrm{P}\left(3,5-\mathrm{C}_{6} \mathrm{H}_{3}\left(\mathrm{CF}_{3}\right)_{2}\right)_{3}\right\}\right]$ where $\mathrm{P}(p$ $\left.\mathrm{C}_{6} \mathrm{H}_{4} \mathrm{CF}_{3}\right)_{3}$ is tris(4-(trifluoromethyl)phenyl)phosphine and $\mathrm{P}\left(3,5-\mathrm{C}_{6} \mathrm{H}_{3}\left(\mathrm{CF}_{3}\right)_{2}\right)_{3}$ is tris $(3,5$ - 
bis(trifluoromethyl)phenyl)phosphine. We investigated the steric and electronic properties of the new complexes through X-ray analysis and cyclic voltammetry. The new complexes were demonstrated to be catalyst precursors for the etherification of propargylic alcohols. The catalytic activity of $\left[\mathrm{RuCl}(\mathrm{ind})\left(\mathrm{PPh}_{3}\right)\left\{\mathrm{P}\left(p-\mathrm{C}_{6} \mathrm{H}_{4} \mathrm{CF}_{3}\right)_{3}\right\}\right]$, [RuCl(ind $)\left(\mathrm{PPh}_{3}\right)\{\mathrm{P}(3,5-$ $\left.\left.\left.\mathrm{C}_{6} \mathrm{H}_{3}\left(\mathrm{CF}_{3}\right)_{2}\right)_{3}\right\}\right]$ and $\left.\left[\mathrm{RuCl}(\mathrm{ind})\left(\mathrm{PPh}_{3}\right)_{2}\right\}\right]$ were compared and potential catalytically active species in the reaction mixture were investigated.

\section{Results and Discussion}

\subsection{Ruthenium complex syntheses.}

The known [7] ruthenium indenyl complex [ $\left.\mathrm{RuCl}(\mathrm{ind})\left(\mathrm{PPh}_{3}\right)_{2}\right]$ has previously been utilized as a starting material for organometallic syntheses by us [12,18] and others [8], as one of the $\mathrm{PPh}_{3}$ ligand can be thermally exchanged by other ligands. Accordingly, when the complex $\left[\mathrm{RuCl}(\mathrm{ind})\left(\mathrm{PPh}_{3}\right)_{2}\right]$ was refluxed with one equivalent of either $\mathrm{P}\left(p-\mathrm{C}_{6} \mathrm{H}_{4} \mathrm{CF}_{3}\right)_{3}$ or $\mathrm{P}(3,5-$ $\left.\mathrm{C}_{6} \mathrm{H}_{3}\left(\mathrm{CF}_{3}\right)_{2}\right)_{3}$ in THF for four hours, the new complexes [RuCl(ind $\left.)\left(\mathrm{PPh}_{3}\right)\left\{\mathrm{P}\left(p-\mathrm{C}_{6} \mathrm{H}_{4} \mathrm{CF}_{3}\right)_{3}\right\}\right]$ and $\left[\mathrm{RuCl}(\mathrm{ind})\left(\mathrm{PPh}_{3}\right)\left\{\mathrm{P}\left(3,5-\mathrm{C}_{6} \mathrm{H}_{3}\left(\mathrm{CF}_{3}\right)_{2}\right)_{3}\right\}\right]$ were isolated chromatographically in 57 and $24 \%$ yields, respectively (Scheme 1). The low yields may be due to decomposition reactions that occur during reaction and workup, as little to no starting material was observed by NMR in the crude products.

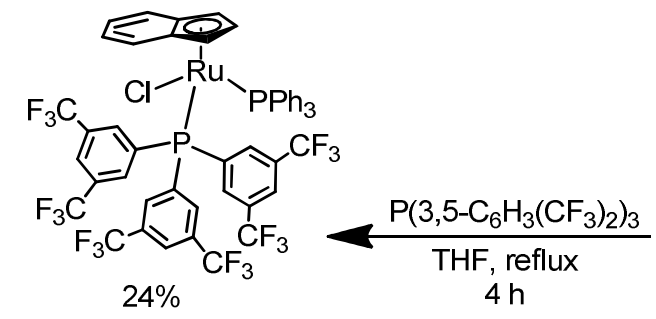

[RuCl(ind) $\left.\left(\mathrm{PPh}_{3}\right)\left\{\mathrm{P}\left(3,5-\left(\mathrm{CF}_{3}\right)_{2} \mathrm{C}_{6} \mathrm{H}_{3}\left(\mathrm{CF}_{3}\right)_{2}\right)_{3}\right\}\right]$

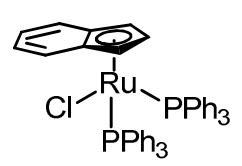

[RuCl(ind) $\left.\left(\mathrm{PPh}_{3}\right)_{2}\right]$

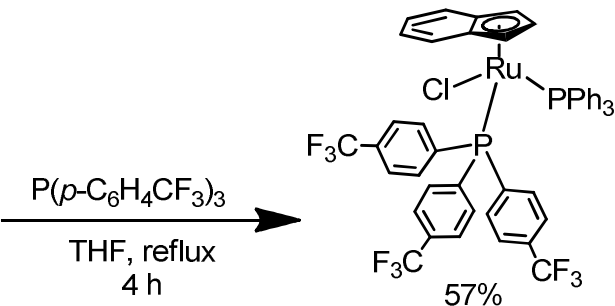

[RuCl(ind) $\left.\left(\mathrm{PPh}_{3}\right)\left\{\mathrm{P}\left(p-\mathrm{C}_{4} \mathrm{H}_{6} \mathrm{CF}_{3}\right)_{3}\right\}\right]$

Scheme 1. Synthesis of ruthenium complexes bearing fluorinated aryl phosphine ligands. 
The new complexes were characterized by multinuclear NMR, MS, IR, elemental analysis and X-ray diffraction. In both complexes, the coordination of one fluorinated phosphine ligand and one $\mathrm{PPh}_{3}$ ligand is readily indicated by two distinct ${ }^{31} \mathrm{P}\left\{{ }^{1} \mathrm{H}\right\}$ NMR signals at 50.1 and $44.2 \mathrm{ppm}$ and at 50.1 and $47.8 \mathrm{ppm}$, respectively. As expected for complexes with two magnetically different phosphorus atoms in the metal coordination sphere, coupling between the two signals was observed. Coupling constants ${ }^{2} J_{\mathrm{PP}}$ of $42 \mathrm{~Hz}$ were determined.

In general, the indenyl ligand gives very distinct ${ }^{1} \mathrm{H}$ and ${ }^{13} \mathrm{C}\left\{{ }^{1} \mathrm{H}\right\}$ NMR signals for the three protons and the five carbon atoms of its coordinated five-membered ring [19]. All these carbon and proton atoms of the indenyl ligand in the new complexes gave individual signals in the corresponding ${ }^{1} \mathrm{H}$ and ${ }^{13} \mathrm{C}\left\{{ }^{1} \mathrm{H}\right\}$ NMR spectra.

\section{2. $X$-ray structures}

In order to unequivocally establish the structure of the new ruthenium complexes, the $\mathrm{X}$ ray structures of $\left[\mathrm{RuCl}(\right.$ ind $\left.)\left(\mathrm{PPh}_{3}\right)\left\{\mathrm{P}\left(p-\mathrm{C}_{6} \mathrm{H}_{4} \mathrm{CF}_{3}\right)_{3}\right\}\right]$ and $\left[\mathrm{RuCl}(\right.$ ind $)\left(\mathrm{PPh}_{3}\right)\{\mathrm{P}(3,5-$ $\left.\left.\left.\mathrm{C}_{6} \mathrm{H}_{3}\left(\mathrm{CF}_{3}\right)_{2}\right)_{3}\right\}\right]$ were determined (Figure 2). Selected bond lengths and angles are listed in Table 1, and for comparison purposes, the X-ray data for [ $\left.\mathrm{RuCl}(\mathrm{ind})\left(\mathrm{PPh}_{3}\right)_{2}\right][20]$ and for $\left[\mathrm{RuCl}(\mathrm{Ind})\left(\mathrm{PPh}_{3}\right)\left\{\mathrm{P}(\mathrm{pyr})_{3}\right\}\right]$ (Figure 1) [12a] from the literature are also included. As previously observed by us [12a], it appears that complexes of the general formula [ $\left.\mathrm{RuCl}(\mathrm{ind})\left(\mathrm{PPh}_{3}\right) \mathrm{L}\right]$ are structurally not significantly different from the "parent" complex $\left[\mathrm{RuCl}(\mathrm{ind})\left(\mathrm{PPh}_{3}\right)_{2}\right]$. For the complex $\left[\mathrm{RuCl}(\mathrm{ind})\left(\mathrm{PPh}_{3}\right)\left\{\mathrm{P}\left(3,5-\mathrm{C}_{6} \mathrm{H}_{3}\left(\mathrm{CF}_{3}\right)_{2}\right)_{3}\right\}\right]$, a face-to-face aromatic donor-acceptor interaction between one of the fluorinated aryl rings and one of the phenyl rings of $\mathrm{PPh}_{3}$ was 
observed (Figure 2, bottom) [21]. The distance between the two aryl ring systems was calculated to be $3.873 \AA$.

The $\mathrm{P}-\mathrm{Ru}-\mathrm{P}$ and $\mathrm{P}-\mathrm{Ru}-\mathrm{Cl}$ bond angles around the ruthenium center range from $91.612(17)^{\circ}$ to $99.585(19)^{\circ}$, and are also similar to the bond angles of the other two complexes listed in Table 1 . The geometry of the new complexes is, thus, best described as slightly distorted octahedral. The somewhat increased P-Ru-P bond angles for the two new complexes indicates some steric repulsion of the $\mathrm{PPh}_{3}$ and the fluorinated ligands. It appears that the bulkier phosphine $\mathrm{P}\left(3,5-\mathrm{C}_{6} \mathrm{H}_{3}\left(\mathrm{CF}_{3}\right)_{2}\right)_{3}$ forms a smaller $\mathrm{P}-\mathrm{Ru}-\mathrm{P}$ angle with $\mathrm{PPh}_{3}$ compared to the less bulky phosphine $\mathrm{P}\left(\mathrm{p}-\mathrm{C}_{6} \mathrm{H}_{4} \mathrm{CF}_{3}\right)_{3}$ which might be a consequence of the face-to-face interaction in the solid state shown in Figure 2. For the other two, structurally related complexes in Table 1, increased P-Ru-P bond angles between the phosphine ligands were observed as well.

The Ru-P bond lengths for the two new complexes range from $2.2696(5)$ to $2.3203(5) \AA$ and are not appreciably different from each other. It appears that the electron-withdrawing character of the fluorinated ligands does not have a profound impact on the Ru-P bond lengths compared to the structurally related complexes $\left[\mathrm{RuCl}(\mathrm{ind})\left(\mathrm{PPh}_{3}\right)_{2}\right]$ and $\left[\mathrm{RuCl}(\mathrm{Ind})\left(\mathrm{PPh}_{3}\right)\left\{\mathrm{P}(\mathrm{pyr})_{3}\right\}\right]$ (Figure 1). Also, the distances between the centroids of the C5 ring of the indenyl ligands and the ruthenium centers for both complexes are similar (1.904 and 1.903 $\AA$ ) and comparable to that for $\left[\mathrm{RuCl}(\mathrm{ind})\left(\mathrm{PPh}_{3}\right)_{2}\right](1.918 \AA$ ) .

As can be seen from the X-ray structures, the indenyl ligands for both complexes are $\eta^{5}$ coordinated, i.e. all five carbon atoms of the cyclopentadienyl unit are coordinated to the ruthenium center. As analyzed previously by us [12a] and others [11e], not all five carbon atoms have the same $\mathrm{Ru}-\mathrm{C}$ bond lengths. The bond lengths of the two benzenoid carbons are longer compared to the other three carbon atoms of the cyclopentadienyl ring. This can be quantified by 
the $\Delta \mathrm{Ru}-\mathrm{C}$ value (here 0.197 and $0.137 \AA$, respectively), which describes the average difference in bond lengths of the two benzenoid carbon atoms and the other three carbon atoms of the cyclopentadienyl unit [11e,12a,22]. Related complexes exhibit similar $\Delta \mathrm{Ru}-\mathrm{C}$ values around 0.2 $\AA$. The fold angle is the angle between the plane formed by C1-C2-C3 of the C5 ring and by C1C3-C4-C5 or C1-C3-C4-C9 of two carbon atoms of the C5 ring and the two carbon atoms shared by the C5 ring and the benzenoyl unit; thus, it describes the angle that is formed by the plane of the C5 unit and the benzene unit of the indenyl ligand [11e]. The fold angle takes the value 0 in an ideal $\eta^{5}$-coordination, and for indenyl complexes, the values typically range below $10^{\circ}$; again, $\left[\mathrm{RuCl}(\mathrm{ind})\left(\mathrm{PPh}_{3}\right)\left\{\mathrm{P}\left(p-\mathrm{C}_{6} \mathrm{H}_{4} \mathrm{CF}_{3}\right)_{3}\right\}\right]$ and $\left[\mathrm{RuCl}(\mathrm{ind})\left(\mathrm{PPh}_{3}\right)\left\{\mathrm{P}\left(3,5-\mathrm{C}_{6} \mathrm{H}_{3}\left(\mathrm{CF}_{3}\right)_{2}\right)_{3}\right\}\right]$ fall in this range $\left(9.57^{\circ}\right.$ and $7.45^{\circ}$, respectively) as do the other two complexes shown in Table 1 . An $\eta^{3}$ coordination would be indicated by a fold angle around $60^{\circ}[11 \mathrm{e}]$.

It has been observed before that the ligand with the strongest trans influence will take the position trans to the benzo unit of the indenyl ligand [11e]. The trans influence weakens the bond strength (and enlarges the bond length) of the two Ru-C bonds of the benzo unit coordinated to the ruthenium. Accordingly, the $\mathrm{PPh}_{3}$ ligand (as opposed to the fluorinated phosphine ligands) takes the position trans to the benzoid portion of the indenylid ligand (schematic structure $\mathbf{A}$ in in Figure 3). This position provides some evidence that $\mathrm{PPh}_{3}$ has a larger trans influence compared to the fluorinated ligands; however the solid state structures allow only limited conclusions for the situation in solution.

In general, it appears that the placement of electron-withdrawing $\mathrm{CF}_{3}$ units on the aryl rings in triarylphosphine ligands does not have a profound impact on the Ru-P bond length and other geometric parameters of their respective ruthenium complexes in the solid state when 
compared to structurally related ones, such as $\left[\mathrm{RuCl}(\mathrm{Ind})\left(\mathrm{PPh}_{3}\right)\left\{\mathrm{P}(\mathrm{pyr})_{3}\right\}\right]($ Figure 1) and $\left[\mathrm{RuCl}(\mathrm{Ind})\left(\mathrm{PPh}_{3}\right)_{2}\right][7]$. 

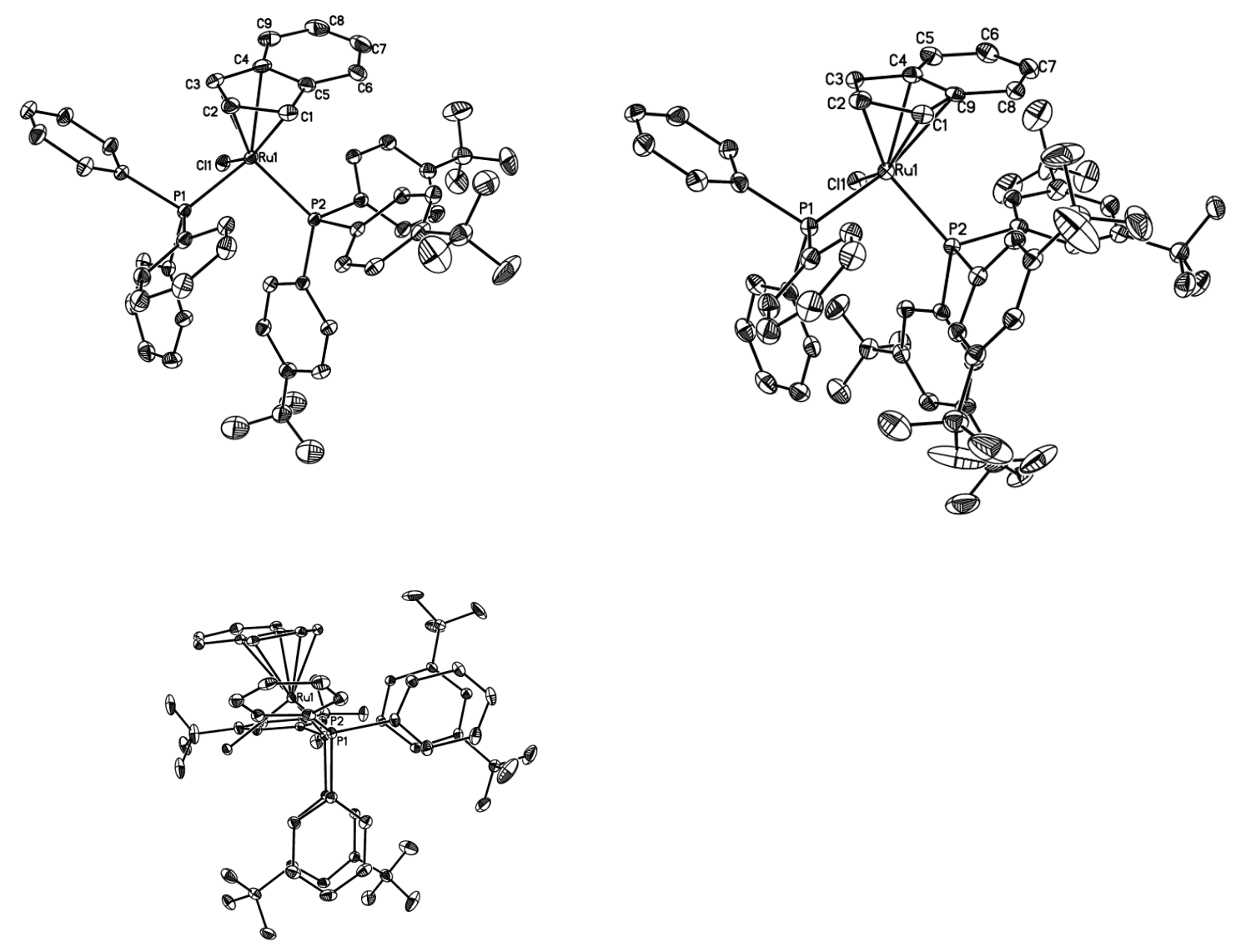

Figure 2. The molecular structures of $\left[\mathrm{RuCl}(\mathrm{ind})\left(\mathrm{PPh}_{3}\right)\left\{\mathrm{P}\left(p-\mathrm{C}_{6} \mathrm{H}_{4} \mathrm{CF}_{3}\right)_{3}\right\}\right]$ (left) and [RuCl(ind) $\left.\left(\mathrm{PPh}_{3}\right)\left\{\mathrm{P}\left(3,5-\mathrm{C}_{6} \mathrm{H}_{3}\left(\mathrm{CF}_{3}\right)_{2}\right)_{3}\right\}\right]$ (right and bottom). Hydrogen atoms are omitted for clarity. Crystallographic parameters are given in the experimental, and key bond lengths and angles are listed in Table 1 . 


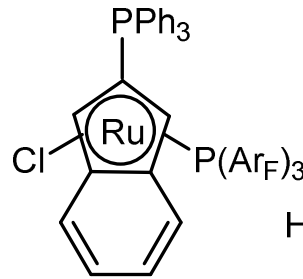

A

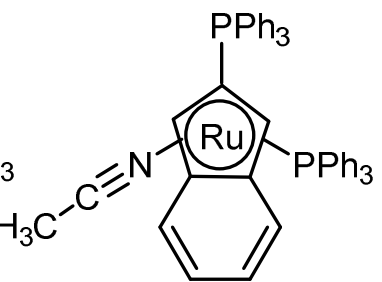

B

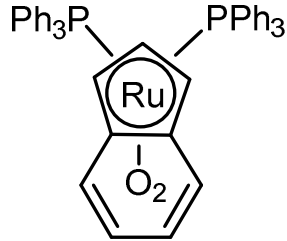

C

Figure 3. Schematic representation of the position of the indenyl ring in the X-ray structures of indenyl complexes determined in this study. $\mathbf{B}$ and $\mathbf{C}$ are discussed later in the text. 
Table 1. Selected bond lengths $(\AA)$ and angles $\left(^{\circ}\right)$ for complexes of the general formula $\left[\mathrm{RuCl}(\mathrm{ind})\left(\mathrm{PPh}_{3}\right) \mathrm{PR}_{3}\right]$

\begin{tabular}{|c|c|c|c|c|}
\hline & $\begin{array}{l}\mathrm{PR}_{3}= \\
\left.\left\{\mathrm{P}\left(p-\mathrm{C}_{6} \mathrm{H}_{4} \mathrm{CF}_{3}\right)_{3}\right\}\right]\end{array}$ & $\begin{array}{l}\mathrm{PR}_{3}=\{\mathrm{P}(3,5- \\
\left.\left.\left.\mathrm{C}_{6} \mathrm{H}_{3}\left(\mathrm{CF}_{3}\right)_{2}\right)_{3}\right\}\right]\end{array}$ & $\begin{array}{l}\mathrm{PR}_{3}=\mathrm{P}(\mathrm{pyr})_{3} \\
\text { (Fig. 1) [12a] }\end{array}$ & $\begin{array}{l}\mathrm{PR}_{3}=\mathrm{PPh}_{3} \\
{[20]}\end{array}$ \\
\hline \multicolumn{5}{|l|}{$\begin{array}{l}\text { Bond } \\
\text { lengths } \\
(\AA)\end{array}$} \\
\hline $\mathrm{Ru}-\mathrm{P}(1)$ & $\begin{array}{l}2.2696(5) \\
\left(\mathrm{PPh}_{3}\right)\end{array}$ & $\begin{array}{l}2.2707(9) \\
\left(\mathrm{PPh}_{3}\right)\end{array}$ & $\begin{array}{l}2.2323(15) \\
\left(\mathrm{P}(\mathrm{Pyr})_{3}\right)\end{array}$ & $\begin{array}{l}2.331 \\
\left(\mathrm{PPh}_{3}\right)\end{array}$ \\
\hline Ru-P(2) & $\begin{array}{l}2.3203(5) \\
\mathrm{P}\left(p-\mathrm{C}_{6} \mathrm{H}_{4} \mathrm{CF}_{3}\right)_{3}\end{array}$ & $\begin{array}{l}2.2929(9) \\
\mathrm{P}\left(3,5-\mathrm{P}_{6} \mathrm{H}_{3}\left(\mathrm{CF}_{3}\right)_{2}\right)_{3}\end{array}$ & $\begin{array}{l}2.2760(14) \\
\left(\mathrm{PPh}_{3}\right)\end{array}$ & $\begin{array}{l}2.268 \\
\left(\mathrm{PPh}_{3}\right)\end{array}$ \\
\hline \multicolumn{5}{|c|}{$\begin{array}{l}\text { Bond } \\
\text { Angles } \\
\left({ }^{\circ}\right)\end{array}$} \\
\hline $\begin{array}{l}\mathrm{P}(1)-\mathrm{Ru}- \\
\mathrm{P}(2)\end{array}$ & 99.585(19) & $95.59(3)$ & $97.89(5)$ & 99.21 \\
\hline $\begin{array}{l}\text { Cl-Ru- } \\
\mathrm{P}(1)\end{array}$ & $92.389(18)$ & 93.03(3) & 93.51(5) & 92.42 \\
\hline $\begin{array}{l}\text { Cl-Ru- } \\
\mathrm{P}(2)\end{array}$ & 91.612(17) & $95.50(3)$ & $91.79(5)$ & 92.19 \\
\hline \multicolumn{5}{|c|}{$\begin{array}{l}\text { Other } \\
\text { geo- } \\
\text { metrical } \\
\text { para- } \\
\text { meters }\end{array}$} \\
\hline $\begin{array}{l}\text { Ru-C5- } \\
\operatorname{ring}(\AA)^{\text {a }}\end{array}$ & 1.904 & 1.903 & 1.902 & 1.918 \\
\hline$\Delta \mathrm{Ru}-\mathrm{C}$ & $0.197^{\mathrm{b}}$ & $0.137^{\mathrm{c}}$ & 0.161 & 0.221 \\
\hline $\begin{array}{l}\text { Fold } \\
\text { angle }\end{array}$ & $9.57^{\circ \mathrm{d}}$ & $7.45^{\circ} \mathrm{e}$ & $7.06^{\circ}$ & $7.07^{\circ}$ \\
\hline
\end{tabular}

${ }^{a}$ Distance between the C5 ring of the indenyl ligand and the ruthenium center.

${ }^{b}$ Average difference between the Ru-C1, Ru-C2 and Ru-C3 bond lengths and the Ru-C4 and Ru-C5 bond lengths.

${ }^{c}$ Average difference between the $\mathrm{Ru}-\mathrm{C} 1, \mathrm{Ru}-\mathrm{C} 2$ and $\mathrm{Ru}-\mathrm{C} 3$ bond lengths and the $\mathrm{Ru}-\mathrm{C} 4$ and $\mathrm{Ru}-$ C9 bond lengths.

$\mathrm{d}$ Angle between the plane formed by $\mathrm{C} 1-\mathrm{C} 2-\mathrm{C} 3$ and by $\mathrm{C} 1-\mathrm{C} 3-\mathrm{C} 4-\mathrm{C} 5$.

e Angle between the plane formed by $\mathrm{C} 1-\mathrm{C} 2-\mathrm{C} 3$ and by $\mathrm{C} 1-\mathrm{C} 3-\mathrm{C} 4-\mathrm{C} 9$. 


\subsection{Cyclic Voltammetry}

Cyclic voltammetry has been used previously to characterize the electronic properties of ruthenium phosphine complexes by us [12a, 23] and others [24], and we recorded cyclic voltammograms of $\left[\mathrm{RuCl}(\mathrm{ind})\left(\mathrm{PPh}_{3}\right)\left\{\mathrm{P}\left(p-\mathrm{C}_{6} \mathrm{H}_{4} \mathrm{CF}_{3}\right)_{3}\right\}\right]$ and $\left[\mathrm{RuCl}(\mathrm{ind})\left(\mathrm{PPh}_{3}\right)\{\mathrm{P}(3,5-\right.$ $\left.\left.\left.\mathrm{C}_{6} \mathrm{H}_{3}\left(\mathrm{CF}_{3}\right)_{2}\right)_{3}\right\}\right]$. The traces for a scan rate of $0.2 \mathrm{~V} / \mathrm{s}$ are compiled in Figure 4.

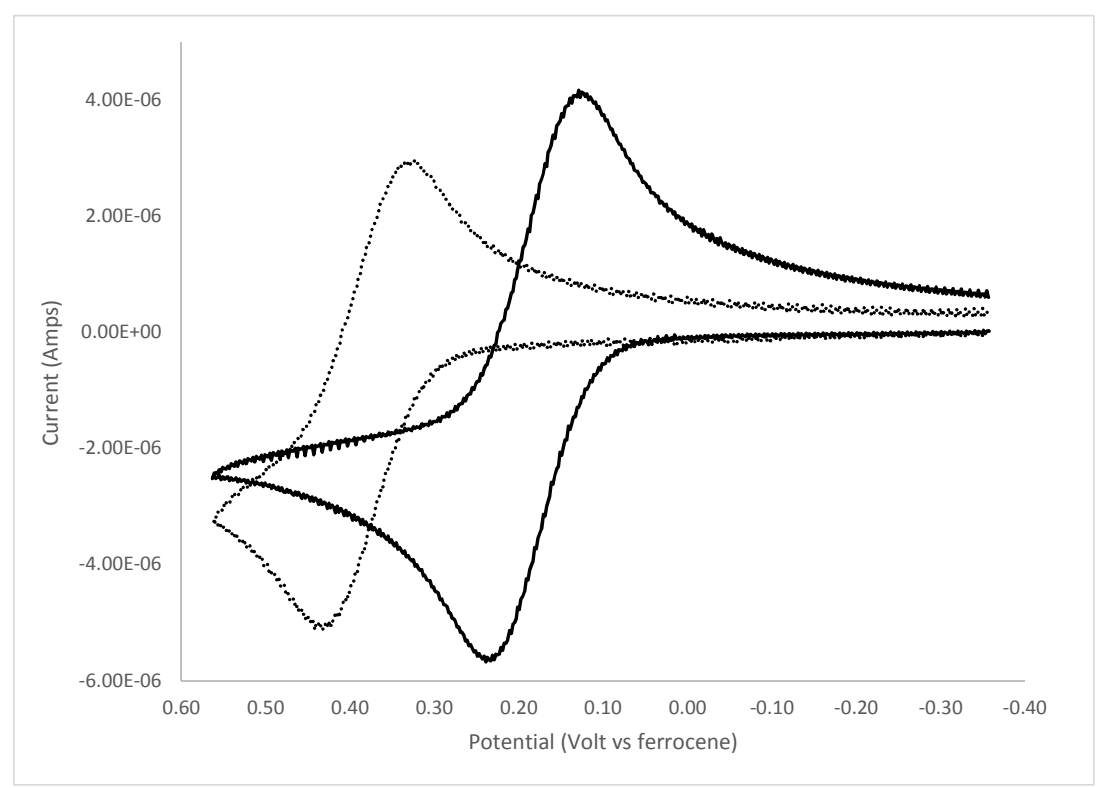

Figure 4. Cyclic voltammetry of ruthenium indenyl complexes in $0.1 \mathrm{M} n-\mathrm{Bu}_{4} \mathrm{PF}_{6} /$ $\mathrm{CH}_{2} \mathrm{Cl}_{2}, 298 \mathrm{~K}$, recorded at a scan rate of $0.2 \mathrm{~V} / \mathrm{s}$., $\left[\mathrm{RuCl}(\mathrm{ind})\left(\mathrm{PPh}_{3}\right)\left\{\mathrm{P}\left(\mathrm{p}-\mathrm{C}_{6} \mathrm{H}_{4} \mathrm{CF}_{3}\right)_{3}\right\}\right](0.92$ $\mathrm{mM}$ concentration, solid line $)$ and $\left[\mathrm{RuCl}(\mathrm{ind})\left(\mathrm{PPh}_{3}\right)\left\{\mathrm{P}\left(3,5-\mathrm{C}_{6} \mathrm{H}_{3}\left(\mathrm{CF}_{3}\right)_{2}\right)_{3}\right\}\right](0.73 \mathrm{mM}$ concentration, dotted line $\cdots)$.

The cyclic voltammograms of $\left[\mathrm{RuCl}(\mathrm{ind})\left(\mathrm{PPh}_{3}\right)\left\{\mathrm{P}\left(p-\mathrm{C}_{6} \mathrm{H}_{4} \mathrm{CF}_{3}\right)_{3}\right\}\right]$ and $\left[\mathrm{RuCl}(\mathrm{ind})\left(\mathrm{PPh}_{3}\right)\left\{\mathrm{P}\left(3,5-\mathrm{C}_{6} \mathrm{H}_{3}\left(\mathrm{CF}_{3}\right)_{2}\right)_{3}\right\}\right]$ show a high degree of reversibility at different scan rates in that its $i_{p c} i_{p a}$ values are close to a value of 1 at all scan rates. The $\mathrm{E}^{\circ}$, value for the 
oxidation is $+0.173 \mathrm{~V}$ (vs. $\mathrm{Cp}_{2} \mathrm{Fe}^{0 /+}, \mathrm{Cp}=$ cyclopentadienyl) and the peak current ratio $i_{p c} / i_{p a}$ is 1.0 at a scan rate of $0.2 \mathrm{~V} / \mathrm{s}$ for $\left[\mathrm{RuCl}(\mathrm{ind})\left(\mathrm{PPh}_{3}\right)\left\{\mathrm{P}\left(p-\mathrm{C}_{6} \mathrm{H}_{4} \mathrm{CF}_{3}\right)_{3}\right\}\right]$. For the complex $\left[\mathrm{RuCl}(\right.$ ind $\left.)\left(\mathrm{PPh}_{3}\right)\left\{\mathrm{P}\left(3,5-\mathrm{C}_{6} \mathrm{H}_{3}\left(\mathrm{CF}_{3}\right)_{2}\right)_{3}\right\}\right]$, the $\mathrm{E}^{\circ}$, value is significantly higher $(+0.370 \mathrm{~V})$. The oxidation of $\left[\mathrm{RuCl}(\mathrm{ind})\left(\mathrm{PPh}_{3}\right)\left\{\mathrm{P}\left(3,5-\mathrm{C}_{6} \mathrm{H}_{3}\left(\mathrm{CF}_{3}\right)_{2}\right)_{3}\right\}\right]$ is also reversible at different scan rates with an $i_{p c} / i_{p a}$ ratio of 0.98 at $0.2 \mathrm{~V} / \mathrm{s}$. It appears that the introduction of $\mathrm{CF}_{3}$-substituted tris(aryl)phosphine ligands increases the redox potential of the respective complexes compared to the "parent" complex $\left[\mathrm{RuCl}(\mathrm{ind})\left(\mathrm{PPh}_{3}\right)_{2}\right]\left(\mathrm{E}^{\circ}=-0.023 \mathrm{~V}\right)[12 \mathrm{a}]$, which is in line with the higher $\pi$-acidic electron-demand of the fluorinated ligands. Interestingly, as determined before in our laboratory, the related complex $\left[\mathrm{RuCl}(\mathrm{ind})\left(\mathrm{PPh}_{3}\right)\left\{\mathrm{P}(\mathrm{pyr})_{3}\right\}\right]$ (Figure 1) exhibited an redox potential of $+0.34 \mathrm{~V}$. Thus, it appears that the $\mathrm{P}(\mathrm{pyr})_{3}$ ligand has a $\pi$-acidity comparable to that of $\mathrm{P}\left(3,5-\mathrm{C}_{6} \mathrm{H}_{3}\left(\mathrm{CF}_{3}\right)_{2}\right)_{3}[12 \mathrm{a}]$

\subsection{Catalytic applications}

We then investigated the new complexes for their ability to catalytically activate propargylic alcohols [25], and we chose as a test reaction the etherification of propargylic alcohol $\mathbf{1 b}$ with benzyl alcohol $\mathbf{2 b}$ to obtain the propargylic ether $\mathbf{3}$ (Table 2). We performed preliminary screening reactions with the more easily available precursor complex $\left[\mathrm{RuCl}(\mathrm{ind})\left(\mathrm{PPh}_{3}\right)_{2}\right]$; reactivity trends established in Table 2 were similar to those observed for the new complexes with the fluorinated ligands. The complexes $\left[\mathrm{RuCl}(\mathrm{ind})\left(\mathrm{PPh}_{3}\right)_{2}\right]$, $\left[\mathrm{RuCl}(\right.$ ind $\left.)\left(\mathrm{PPh}_{3}\right)\{\mathrm{P}(p-\mathrm{C} 6 \mathrm{H} 4 \mathrm{CF} 3) 3\}\right]$ and $\left[\mathrm{RuCl}(\mathrm{ind})\left(\mathrm{PPh}_{3}\right)\left\{\mathrm{P}\left(3,5-\mathrm{C}_{6} \mathrm{H}_{3}\left(\mathrm{CF}_{3}\right)_{2}\right)_{3}\right\}\right]$ themselves did not show catalytic activity for the reaction. However, after activation by chloride abstraction using $\mathrm{NaPF}_{6}$, catalytic activity was observed. 
Table 2. Screening Reactions

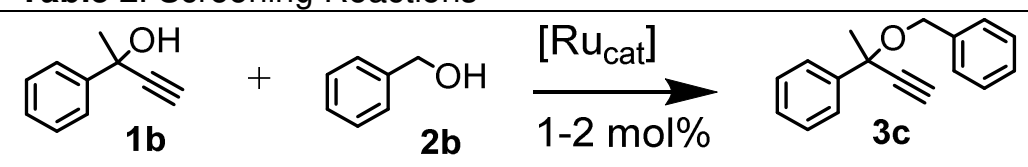

\begin{tabular}{|c|c|c|c|c|c|}
\hline Entry & Solvent & $T-t$ & Catalyst $^{\top}$ & Activator $^{2}$ & Results / Products \\
\hline 1 & $\begin{array}{l}\mathrm{CH}_{3} \mathrm{CN} / \\
\text { toluene } \\
1: 9\end{array}$ & $\begin{array}{l}80^{\circ} \mathrm{C} \\
8 \mathrm{~h}\end{array}$ & {$\left[\right.$ RuCl(ind) $\left.\left(\mathrm{PPh}_{3}\right)_{2}\right]$} & $\begin{array}{l}1 \text { equiv. } \\
\mathrm{NaPF}_{6}\end{array}$ & no reaction \\
\hline 2 & $\begin{array}{l}\mathrm{CH}_{3} \mathrm{CN} / \\
\text { toluene } \\
1: 9\end{array}$ & $\begin{array}{l}80^{\circ} \mathrm{C} \\
4 \mathrm{~h}\end{array}$ & {$\left[\mathrm{RuCl}(\mathrm{ind})\left(\mathrm{PPh}_{3}\right)_{2}\right]$} & $\mathrm{KPF}_{6}$ & no reaction \\
\hline 3 & $\begin{array}{l}\mathrm{CH}_{3} \mathrm{CN} / \\
\text { toluene } \\
1: 9\end{array}$ & $\begin{array}{l}80^{\circ} \mathrm{C} \\
16 \mathrm{~h}\end{array}$ & {$\left[\mathrm{RuCl}(\right.$ ind $\left.)\left(\mathrm{PPh}_{3}\right)_{2}\right]$} & $\mathrm{NaClO}_{4}$ & no reaction \\
\hline 4 & $\begin{array}{l}\mathrm{CH}_{3} \mathrm{CN} / \\
\text { toluene } \\
1: 9\end{array}$ & $\begin{array}{l}80^{\circ} \mathrm{C} \\
4 \mathrm{~h}\end{array}$ & {$\left[\mathrm{RuCl}(\mathrm{ind})\left(\mathrm{PPh}_{3}\right)_{2}\right]$} & $\begin{array}{l}6 \text { equiv. } \\
\mathrm{NaPF}_{6}\end{array}$ & \\
\hline \multirow[t]{2}{*}{5} & toluene & $\begin{array}{l}80^{\circ} \mathrm{C} \\
16 \mathrm{~h}\end{array}$ & {$\left[\mathrm{Ru}(\right.$ ind $\left.)(\mathrm{MeCN})\left(\mathrm{PPh}_{3}\right)_{2}\right] \mathrm{PF}_{6}{ }^{3}$} & none & \\
\hline & & & & & $44 \%$ isolated yield \\
\hline 6 & toluene & $\begin{array}{l}85^{\circ} \mathrm{C} \\
4 \mathrm{~h}\end{array}$ & none & $\mathrm{NaPF}_{6}$ & \\
\hline & & & & & $\begin{array}{l}\text { incomplete, } \\
\text { only elimination }\end{array}$ \\
\hline 7 & toluene & $\begin{array}{l}85^{\circ} \mathrm{C} \\
4 \mathrm{~h}\end{array}$ & {$\left[\mathrm{Ru}(\mathrm{ind})(\mathrm{MeCN})\left(\mathrm{PPh}_{3}\right)_{2}\right] \mathrm{BAr}_{\mathrm{F}}{ }^{4}$} & none & $\begin{array}{l}\text { Trace amounts of } \\
\text { ether product }\end{array}$ \\
\hline
\end{tabular}

\footnotetext{
$11-2 \mathrm{~mol} \%$

${ }^{2}$ Number of equivalents for the activator given in relation to the ruthenium catalyst.

${ }^{3}$ Preformed, chloride-abstracted complex obtained from reaction with $\mathrm{NaPF}_{6}$, see text.

${ }^{4}$ Preformed, chloride-abstracted complex obtained from reaction with $\mathrm{NaBAr}_{\mathrm{F}}$. $\mathrm{BAr}_{\mathrm{F}}=$ Tetrakis(3,5-bis(trifluoromethyl)phenyl)borate, see text.
}

In general, a high-boiling, aliphatic solvent (such as toluene) was required to observe catalytic activity. However, $\mathrm{NaPF}_{6}$ is minimally soluble in toluene and we determined that the 
addition of a small amount of $\mathrm{CH}_{3} \mathrm{CN}$ aided the dissolution of $\mathrm{NaPF}_{6}$. Accordingly, the best results were obtained, when a $1: 9$ ratio of $\mathrm{CH}_{3} \mathrm{CN}$ to toluene in the presence of 4 to 6 equivalents of $\mathrm{NaPF}_{6}$ (related to the ruthenium catalyst) was employed for the reaction (Table 2, entry 4; one equivalent of $\mathrm{NaPF}_{6}$ was insufficient, entry 1). Other chloride abstractors such as $\mathrm{KPF}_{6}$ and $\mathrm{NaClO}_{4}$ obviously did not activate the ruthenium precursor complex as no reaction was observed (entries 2 and 3 ), which might be due to the poor solubility in the solvent mixture. $\mathrm{NaPF}_{6}$ alone gave no etherification product, but resulted in some elimination (entry 6).

Under optimized conditions, the complexes and $\mathrm{NaPF}_{6}$ were first preheated to $85{ }^{\circ} \mathrm{C}$ for 20 minutes in $\mathrm{CH}_{3} \mathrm{CN} /$ toluene $1: 9$, followed by addition of the substrates to the preactivated complex. The activated complexes were employed in a number of etherification reactions to give the known [12d] propargylic ethers $\mathbf{3}$, and the results are compiled in Scheme 2. All three precursor complexes $\left[\mathrm{RuCl}(\right.$ ind $\left.)\left(\mathrm{PPh}_{3}\right)_{2}\right],\left[\mathrm{RuCl}(\mathrm{ind})\left(\mathrm{PPh}_{3}\right)\left\{\mathrm{P}\left(p-\mathrm{C}_{6} \mathrm{H}_{4} \mathrm{CF}_{3}\right)_{3}\right\}\right]$ and [RuCl(ind) $\left.\left(\mathrm{PPh}_{3}\right)\left\{\mathrm{P}\left(3,5-\mathrm{C}_{6} \mathrm{H}_{3}\left(\mathrm{CF}_{3}\right)_{2}\right)_{3}\right\}\right]$ were employed in catalysis (experimental details are given in the Supplementary data), and the yields given in Scheme 2 are for the precursor complexes bearing fluorinated aryl rings. As can be seen, the isolated yields do not significantly differ for the complexes. The isolated yields are moderate; however, the propargylic alcohol and the alcohol nucleophile were employed in almost equimolar amounts. Excess of the alcohol nucleophile over the propargylic alcohol is not required, as sometimes reported for other catalytic systems [25e]. Also, the catalyst load used of $1-2 \mathrm{~mol} \%$ is lower than that of many other catalyst systems reported in the literature [25e]. 


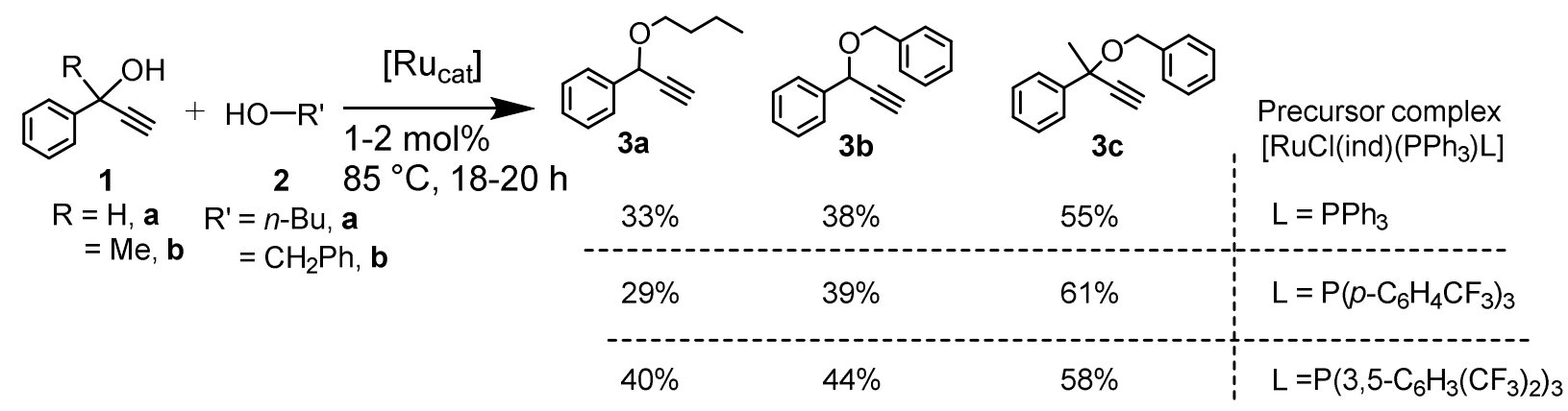

Scheme 2. Catalytic application of the new ruthenium complexes

Thus, the activated complexes exhibited catalytic activity, but we could not reach our major goal, i.e. to lower the reaction temperature and to increase the yield of the reactions. In order to improve the catalyst system and to investigate the course of the reaction in greater detail, we performed additional experiments.

\subsection{Chloride abstraction products}

We first speculated that the chloride abstraction to activate the complexes was inefficient. We, thus, investigated the chloride abstraction by heating the complexes for several hours in presence of $\mathrm{NaPF}_{6}$ and $\mathrm{CH}_{3} \mathrm{CN}$ but without any substrates, and investigated the result by ${ }^{31} \mathrm{P}\left\{{ }^{1} \mathrm{H}\right\}$ NMR. The ${ }^{31} \mathrm{P}\left\{{ }^{1} \mathrm{H}\right\}$ NMR spectra are shown in Figure 5.

The parent complex $\left[\mathrm{RuCl}(\mathrm{ind})\left(\mathrm{PPh}_{3}\right)_{2}\right]$ gave a relatively clean (albeit incomplete) reaction to the corresponding acetonitrile complex $\left[\mathrm{Ru}(\text { ind })\left(\mathrm{CH}_{3} \mathrm{CN}\right)\left(\mathrm{PPh}_{3}\right)_{2}\right]^{+}$, as indicated by a new ${ }^{31} \mathrm{P}\left\{{ }^{1} \mathrm{H}\right\}$ NMR peak at $47.7 \mathrm{ppm}$ (Figure 5, bottom, see also vide infra for the independent synthesis of that complex). For the two other complexes $\left[\mathrm{RuCl}(\mathrm{ind})\left(\mathrm{PPh}_{3}\right)\{\mathrm{P}(\mathrm{p}-\mathrm{C} 6 \mathrm{H} 4 \mathrm{CF} 3) 3\}\right]$ and $\left[\mathrm{RuCl}(\mathrm{ind})\left(\mathrm{PPh}_{3}\right)\{\mathrm{P}(3,5-\mathrm{C} 6 \mathrm{H} 3(\mathrm{CF} 3) 2) 3\}\right]$ with phosphorylated ligands, the reaction was not as clean (Figure 5, middle and top) and a number of new peaks appeared in the ${ }^{31} \mathrm{P}\left\{{ }^{1} \mathrm{H}\right\} \mathrm{NMR}$ spectra. For the complex [RuCl(ind) $\left.\left(\mathrm{PPh}_{3}\right)\left\{\mathrm{P}\left(p-\mathrm{C}_{6} \mathrm{H}_{4} \mathrm{CF}_{3}\right)_{3}\right\}\right]$, the starting material was 
consumed (Figure 5, middle). Besides a couple of unidentified singlets around $48 \mathrm{ppm}$, the reaction mixture after chloride abstraction revealed a set of relatively small doublets at 49.3 and $47.4 \mathrm{ppm}\left(J_{\mathrm{PP}}=35 \mathrm{~Hz}\right)$, which was, based on the synthesis of an authentic sample (vide infra), attributed to the acetonitrile complex $\left[\mathrm{Ru}(\mathrm{ind})\left(\mathrm{CH}_{3} \mathrm{CN}\right)\left(\mathrm{PPh}_{3}\right)\left\{\mathrm{P}\left(p-\mathrm{C}_{6} \mathrm{H}_{4} \mathrm{CF}_{3}\right)_{3}\right\}\right]^{+}$. The complex [RuCl(ind) $\left.\left(\mathrm{PPh}_{3}\right)\left\{\mathrm{P}\left(3,5-\mathrm{C}_{6} \mathrm{H}_{3}\left(\mathrm{CF}_{3}\right)_{2}\right)_{3}\right\}\right]$ gave only partial chloride abstraction, as indicated by corresponding peaks for the starting material in the ${ }^{31} \mathrm{P}\left\{{ }^{1} \mathrm{H}\right\}$ NMR spectrum (Figure 5, top). Only some minor singlets were observed in the spectrum between 47 and $55 \mathrm{ppm}$. It appears that the more electron-poor complex $\left[\mathrm{RuCl}(\mathrm{ind})\left(\mathrm{PPh}_{3}\right)\left\{\mathrm{P}\left(3,5-\mathrm{C}_{6} \mathrm{H}_{3}\left(\mathrm{CF}_{3}\right)_{2}\right)_{3}\right\}\right]$ is - compared to the other two complexes - more difficult to ionize. 

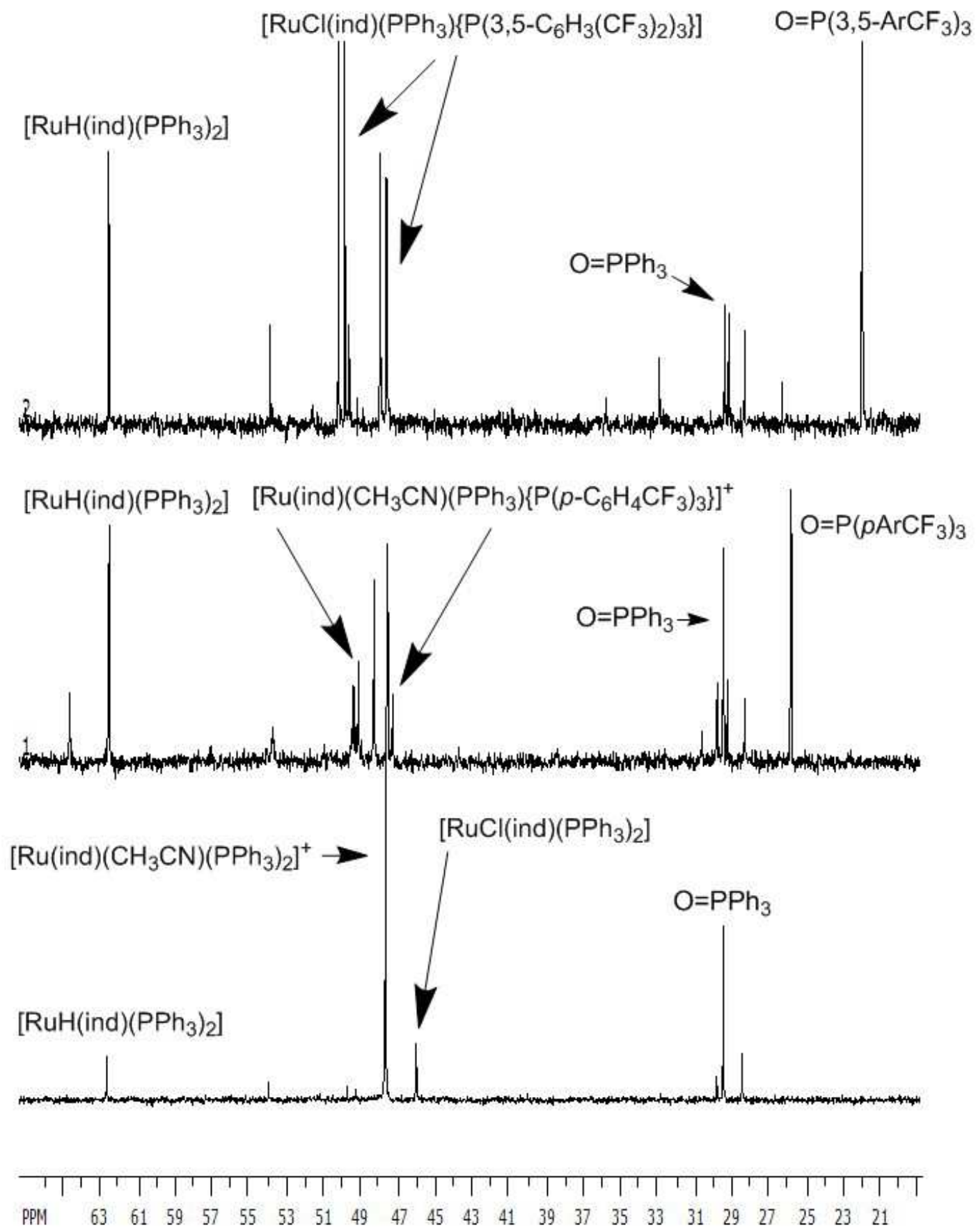

Figure 5. ${ }^{31} \mathrm{P}\left\{{ }^{1} \mathrm{H}\right\} \mathrm{NMR}$ specctra of the complexes $\left[\mathrm{RuCl}(\mathrm{ind})\left(\mathrm{PPh}_{3}\right)\{\mathrm{P}(3,5-\right.$

$\left.\left.\left.\left(\mathrm{CF}_{3}\right)_{2} \mathrm{C}_{6} \mathrm{H}_{3}\right)_{3}\right\}\right]$ (top), [RuCl(ind) $\left.\left(\mathrm{PPh}_{3}\right)\left\{\mathrm{P}\left(p-\mathrm{CF}_{3} \mathrm{C}_{6} \mathrm{H}_{4}\right)_{3}\right\}\right]$ (middle) and [RuCl(ind) $\left.\left(\mathrm{PPh}_{3}\right)_{2}\right]$ (bottom) after treatment with $\mathrm{NaPF}_{6}$. 
For all three complexes, peaks between 21 and 30 ppm indicated the presence of the oxidized ligands $\mathrm{O}=\mathrm{PPh}_{3}(29 \mathrm{ppm}), \mathrm{O}=\mathrm{P}\left(p-\mathrm{C}_{6} \mathrm{H}_{4} \mathrm{CF}_{3}\right)_{3}(25.8 \mathrm{ppm})$ and $\mathrm{O}=\mathrm{P}\left(3,5-\mathrm{C}_{6} \mathrm{H}_{3}\left(\mathrm{CF}_{3}\right)_{2}\right)_{3}$ (21.8 ppm). The peak assignments for the latter two phosphine oxides were performed based on NMR experiments, where the corresponding phosphine ligands were oxidized with small amounts of $\mathrm{H}_{2} \mathrm{O}_{2}$ in $\mathrm{CDCl}_{3}$ and NMR spectra subsequently recorded.

However, we were intrigued by the fact that the chloride abstraction experiments resulted in a resonance around $63 \mathrm{ppm}$ for all three complexes, indicating the formation of a common species (Figure 5). Furthermore, we observed a peak at $-12 \mathrm{ppm}$ in the ${ }^{1} \mathrm{H}$ NMR spectrum of [RuCl(ind) $\left.\left(\mathrm{PPh}_{3}\right)_{2}\right]$ after chloride abstraction, pointing towards formation of a hydrido complex. Indeed, comparison with literature values showed that the ${ }^{1} \mathrm{H}$ and ${ }^{31} \mathrm{P}\left\{{ }^{1} \mathrm{H}\right\}$ NMR resonances for the known hydrido complex $\left[\mathrm{RuH}(\mathrm{ind})\left(\mathrm{PPh}_{3}\right)_{2}\right]$ matches those observed in the reaction mixture after chloride abstraction [7]. Thus, it appeared that the complexes [Ru(ind) $\left(\mathrm{PPh}_{3}\right)\{\mathrm{P}(p$ $\left.\left.\left.\mathrm{C}_{6} \mathrm{H}_{4} \mathrm{CF}_{3}\right)_{3}\right\}\right]^{+}$and $\left[\mathrm{Ru}(\text { ind })\left(\mathrm{PPh}_{3}\right)\left\{\mathrm{P}\left(3,5-\mathrm{C}_{6} \mathrm{H}_{3}\left(\mathrm{CF}_{3}\right)_{2}\right)_{3}\right\}\right]^{+}$undergo ligand metathesis to form [Ru(ind) $\left.\left(\mathrm{PPh}_{3}\right)_{2}\right]^{+}$, which then forms the hydrido complex $\left[\mathrm{RuH}(\mathrm{ind})\left(\mathrm{PPh}_{3}\right)_{2}\right]$. It is known that ruthenium complexes can form hydrides in the presence of alcohols or water [26]. In order to determine whether the hydrido complex $\left[\mathrm{RuH}(\mathrm{ind})\left(\mathrm{PPh}_{3}\right)_{2}\right]$ is the actual catalytically active species in solution, we synthesized the complex independently following a literature procedure [7] and employed it as catalyst in test reactions under the conditions in Scheme 2. Unfortunately, the complex showed no catalytic activity under these conditions. Thus, the formation of the complex $\left[\mathrm{RuH}(\mathrm{ind})\left(\mathrm{PPh}_{3}\right)_{2}\right]$ constitutes a decomposition pathway of the chloro complexes, resulting potentially in catalyst deactivation. 


\subsection{Syntheses of Acetonitrile Complexes and their Reactivity}

It is known that ruthenium forms stable acetonitrile $\left(\mathrm{CH}_{3} \mathrm{CN}\right)$ complexes [27]. We next decided to determine whether analytically pure acetonitrile complexes could be employed as catalysts for the title reaction. Accordingly, we synthesized the complex [Ru(ind) $\left.\left(\mathrm{CH}_{3} \mathrm{CN}\right)\left(\mathrm{PPh}_{3}\right)_{2}\right] \mathrm{PF}_{6}$ according to literature procedures for the corresponding known tetrafluoroborate complex $\left[\mathrm{Ru}\right.$ (ind) $\left.\left(\mathrm{CH}_{3} \mathrm{CN}\right)\left(\mathrm{PPh}_{3}\right)_{2}\right]{ }^{+} \mathrm{BF}_{4}$, as there was no ${ }^{31} \mathrm{P}\left\{{ }^{1} \mathrm{H}\right\} \mathrm{NMR}$ spectrum published together with its synthesis (Scheme 3) [28]. The tetrafluoroborate complex has previously been characterized by ${ }^{1} \mathrm{H}$ NMR and X-ray; for comparison purposes in Figure 5, in addition we analyzed the complex by ${ }^{31} \mathrm{P}\left\{{ }^{1} \mathrm{H}\right\}$ NMR and IR. Following the same procedure, we also synthesized the new acetonitrile complex $\left[\mathrm{Ru}(\mathrm{ind})\left(\mathrm{CH}_{3} \mathrm{CN}\right)\left(\mathrm{PPh}_{3}\right)\{\mathrm{P}(p-\right.$ $\left.\left.\left.\mathrm{C}_{6} \mathrm{H}_{4} \mathrm{CF}_{3}\right)_{3}\right\}\right] \mathrm{PF}_{6}$, which was characterized by ${ }^{1} \mathrm{H}$ and ${ }^{31} \mathrm{P}\left\{{ }^{1} \mathrm{H}\right\}$ NMR and mass spectrometry (Scheme 3). The molecular ion $\left[\mathrm{Ru}(\mathrm{ind})\left(\mathrm{CH}_{3} \mathrm{CN}\right)\left(\mathrm{PPh}_{3}\right)\left\{\mathrm{P}\left(p-\mathrm{C}_{6} \mathrm{H}_{4} \mathrm{CF}_{3}\right)_{3}\right\}\right]^{+}$was not observed, but only the fragment $\left[\mathrm{Ru}(\mathrm{ind})\left(\mathrm{PPh}_{3}\right)\left\{\mathrm{P}\left(p-\mathrm{C}_{6} \mathrm{H}_{4} \mathrm{CF}_{3}\right)_{3}\right\}\right]^{+}$which resulted from $\mathrm{CH}_{3} \mathrm{CN}$ loss. The fragmentation pattern for the complex and the ${ }^{31} \mathrm{P}\left\{{ }^{1} \mathrm{H}\right\}$ NMR shifts differed from those of [RuCl(ind) $\left.\left(\mathrm{PPh}_{3}\right)\left\{\mathrm{P}\left(p-\mathrm{C}_{6} \mathrm{H}_{4} \mathrm{CF}_{3}\right)_{3}\right\}\right]$, which provides strong evidence that a new complex had formed. However, we observed a molecular ion for the fragment $\left[\mathrm{Ru}(\mathrm{ind})\left(\mathrm{CH}_{3} \mathrm{CN}\right)\left(\mathrm{PPh}_{3}\right)\{\mathrm{P}(p-\right.$ $\left.\left.\left.\mathrm{C}_{6} \mathrm{H}_{4} \mathrm{CF}_{3}\right)_{3}\right\}\right]^{+}$in the ESI-MS spectrum. Unfortunately, attempts to convert [RuCl(ind) $\left.\left(\mathrm{PPh}_{3}\right)\left\{\mathrm{P}\left(3,5-\mathrm{C}_{6} \mathrm{H}_{3}\left(\mathrm{CF}_{3}\right)_{2}\right)_{3}\right\}\right]$ to the corresponding acetonitrile complex failed, which could be a consequence of the fact that for this complex chloride abstraction with $\mathrm{NaPF}_{6}$ is more difficult, as was demonstrated in Figure 5. 


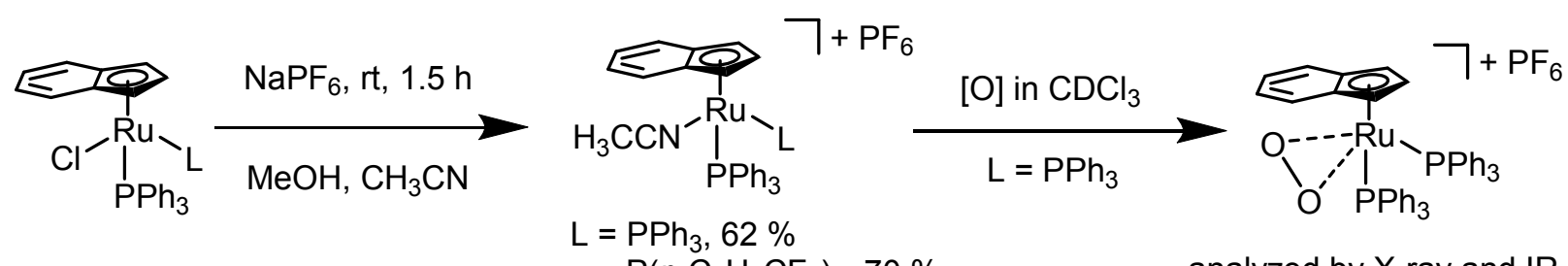

Scheme 3. Synthesis of acetonitrile complexes $\left[R u(\text { ind })\left(\mathrm{CH}_{3} \mathrm{CN}\right)\left(\mathrm{PPh}_{3}\right)\{\mathrm{L}\}\right]^{+} \mathrm{PF}_{6}$.

The complex $\left[\mathrm{Ru}\left(\right.\right.$ ind) $\left.\left(\mathrm{CH}_{3} \mathrm{CN}\right)\left(\mathrm{PPh}_{3}\right)_{2}\right] \mathrm{PF}_{6}$ was also characterized structurally (Figure 6). Selected bond lengths and angles are listed in Table 3. Structural details will be discussed further below. During our characterization efforts for $\left[\mathrm{Ru}(\right.$ ind $\left.)\left(\mathrm{CH}_{3} \mathrm{CN}\right)\left(\mathrm{PPh}_{3}\right)_{2}\right] \mathrm{PF}_{6}$ by NMR, we observed the formation of red crystals precipitating out of the $\mathrm{CDCl}_{3}$ solution in the NMR tube. X-ray analysis revealed that the red crystals are a peroxo complex $\left[\mathrm{Ru}(\mathrm{ind})\left(\eta^{2}-\right.\right.$ $\left.\left.\mathrm{O}_{2}\right)\left(\mathrm{PPh}_{3}\right)_{2}\right] \mathrm{PF}_{6}$, where $\mathrm{O}_{2}$ is coordinated as $\eta^{2}$ side-on to the ruthenium center (Scheme 3). A number of ruthenium complexes with $\eta^{2}$-coordinated $\mathrm{O}_{2}$ have been structurally characterized [29], and they are typically obtained from a ruthenium precursor complex upon reaction with $\mathrm{O}_{2}$. However, attempts to synthesize the complex $\left[\mathrm{Ru}(\mathrm{ind})\left(\eta^{2}-\mathrm{O}_{2}\right)\left(\mathrm{PPh}_{3}\right)_{2}\right] \mathrm{PF}_{6}$ in bulk failed. Also, analysis of the crystals of $\left[\mathrm{Ru}(\right.$ ind $\left.)\left(\eta^{2}-\mathrm{O}_{2}\right)\left(\mathrm{PPh}_{3}\right)_{2}\right] \mathrm{PF}_{6}$ by FAB and ESI-MS did not give a molecular ion peak as proof of the coordination (or the presence) of $\mathrm{O}_{2}$ in the sample. The coordination of $\mathrm{O}_{2}$ might be reversible, as noted previously by others [29a], making characterization efforts more difficult. However, the IR spectrum of the complex in the solid state exhibited an intense absorption at $828 \mathrm{~cm}^{-1}$; this absorption is in accordance with $\eta^{2}$ coordinated $\mathrm{O}_{2}$, which typically shows bands between 800 and $900 \mathrm{~cm}^{-1}$ [30]. The X-ray data of 
$\left[\mathrm{Ru}(\mathrm{ind})\left(\eta^{2}-\mathrm{O}_{2}\right)\left(\mathrm{PPh}_{3}\right)_{2}\right] \mathrm{PF}_{6}$ together with those of its precursor complex

$\left[\mathrm{Ru}(\right.$ ind $\left.)\left(\mathrm{CH}_{3} \mathrm{CN}\right)\left(\mathrm{PPh}_{3}\right)_{2}\right] \mathrm{PF}_{6}$ are presented in Figure 6 and Table 3.
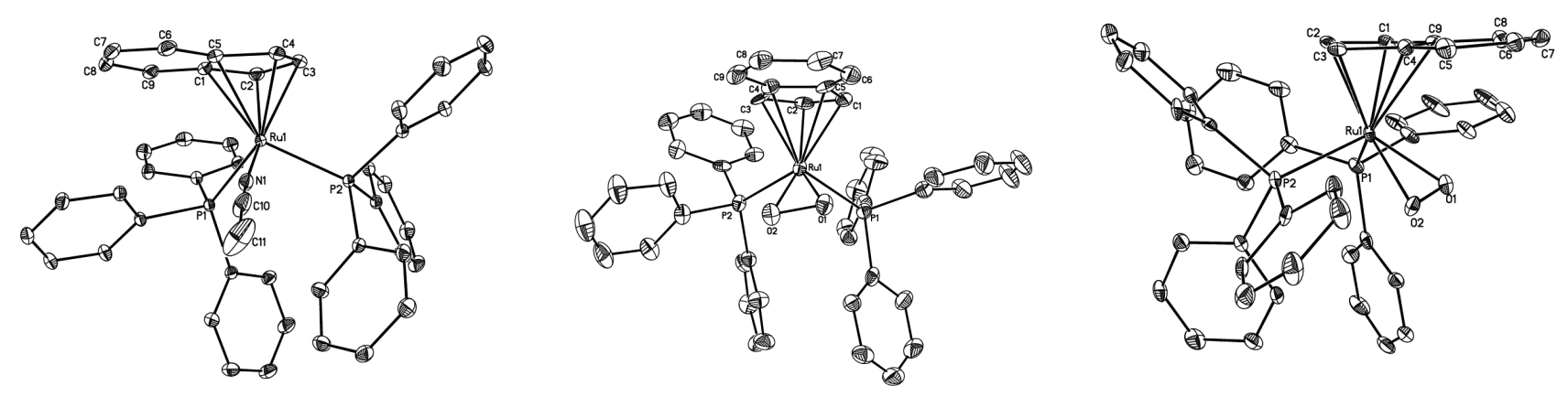

Figure 6. The molecular structures of $\left[\mathrm{Ru}(\right.$ ind $\left.)\left(\mathrm{CH}_{3} \mathrm{CN}\right)\left(\mathrm{PPh}_{3}\right)_{2}\right] \mathrm{PF}_{6}$ (left) and $\left[\mathrm{Ru}(\right.$ ind $)\left(\eta^{2}-\right.$ $\left.\left.\mathrm{O}_{2}\right)\left(\mathrm{PPh}_{3}\right)_{2}\right] \mathrm{PF}_{6}$ (middle and right). Hydrogen atoms and $\mathrm{PF}_{6}{ }^{-}$counterions are omitted for clarity. Crystallographic parameters are compiled in the experimental, and key bond lengths and angles are listed in Table 3.

In both complexes the ruthenium centers are slightly distorted octahedra. The acetonitrile complex $\left[\mathrm{Ru}(\mathrm{ind})\left(\mathrm{CH}_{3} \mathrm{CN}\right)\left(\mathrm{PPh}_{3}\right)_{2}\right] \mathrm{PF}_{6}$ is structurally related to the tetrafluoroborate analog previously described in the literature [28]. The bond lengths [2.0436(12) to (2.3913(4) $\AA$ )] are comparable to those in the complexes bearing the fluorinated ligands described above despite the fact that the complex is cationic. The bond angles around the ruthenium center in [Ru(ind) $\left.\left(\mathrm{CH}_{3} \mathrm{CN}\right)\left(\mathrm{PPh}_{3}\right)_{2}\right] \mathrm{PF}_{6}$ are also similar except for the $\mathrm{P}(1)-\mathrm{Ru}-\mathrm{P}(2)$ angle, which is larger $\left[103.540(12)^{\circ}\right]$ compared to those of the complexes in Table 1 (all below $100^{\circ}$ ). The linear $\mathrm{CH}_{3} \mathrm{CN}$ ligand is obviously less spatially demanding compared to a $\mathrm{Cl}$, allowing for a larger $\mathrm{P}(1)-\mathrm{Ru}-\mathrm{P}(2)$ angle to better accommodate the bulky $\mathrm{PPh}_{3}$ ligands coordinated to the ruthenium 
center. The parameters corroborating the $\eta^{5}$-coordination of the indenyl ligand $(\Delta \mathrm{Ru}-\mathrm{C}$ and the fold angle) are similar to those in Table 1 , which also holds true for the $\eta^{2}-\mathrm{O}_{2}$ complex. As discussed above for the other complexes, one of the two $\mathrm{PPh}_{3}$ ligands takes the position trans to the benzoid carbon atoms of the cyclopentadienyl unit of the indenylid ligand (B in Figure 3), demonstrating the stronger trans influence of $\mathrm{PPh}_{3}$ compared to $\mathrm{CH}_{3} \mathrm{CN}$.

However, it seems that for the complex $\left[\mathrm{Ru}(\mathrm{ind})\left(\eta^{2}-\mathrm{O}_{2}\right)\left(\mathrm{PPh}_{3}\right)_{2}\right] \mathrm{PF}_{6}$, the bond lengths around the ruthenium center are slightly longer compared to the other complexes. The average $\mathrm{Ru}-\mathrm{P}$ bond length is slightly longer and the Ru-Cp distance between the ruthenium center and the centroid of the $\eta^{5}$-coordinated Cp unit of the indenyl ligand is about $0.06 \AA$ longer. The O(1)$\mathrm{O}(2)$ bond length is $1.409(6) \AA$ and, thus, considerably longer compared to the O-O bond length in $\mathrm{O}_{2}\left(1.21 \AA\right.$ ) [30], as expected for side-on coordinated $\mathrm{O}_{2}$. Similar O-O bond length values have been observed before in metal peroxo complexes [29b], and they lie in between the bond lengths for superoxide $\left(\mathrm{KO}_{2}, 1.28 \AA\right)$ [30] and peroxide $\left(\mathrm{O}_{2}{ }^{2-} 1.49 \AA\right)$ [30]. Most interestingly, the $\eta^{2}-\mathrm{O}_{2}$ ligand is aligned parallel to the indenyl ligand ( $\mathbf{C}$ in Figure 3$)$. Typically, the indenyl ligand occupies an interstitial site between the two phosphine ligands (A and $\mathbf{B}$ in Figure 3). 
Table 3. Selected bond lengths $(\AA)$ and angles $\left({ }^{\circ}\right)$

$$
\left[\mathrm{Ru}(\text { ind })\left(\mathrm{CH}_{3} \mathrm{CN}\right)\left(\mathrm{PPh}_{3}\right)_{2}\right] \mathrm{PF}_{6} \quad\left[\mathrm{Ru}(\text { ind })\left(\mathrm{O}_{2}\right)\left(\mathrm{PPh}_{3}\right)_{2}\right] \mathrm{PF}_{6}
$$

Bond lengths

(A)

$\begin{array}{lll}\mathrm{Ru}-\mathrm{P}(1) & 2.3913(4) & 2.3415(16) \\ \mathrm{Ru}-\mathrm{P}(2) & 2.2958(4) & 2.3782(17) \\ \mathrm{Ru}-\mathrm{X} & 2.0436(12)[\mathrm{X}=\mathrm{N}(1)] & 2.003(5)[\mathrm{X}=\mathrm{O}(1)] \\ \mathrm{Ru}-\mathrm{X} & - & 2.008(5)[\mathrm{X}=\mathrm{O}(2)] \\ \mathrm{O}(1)-\mathrm{O}(2) & - & 1.409(6)\end{array}$

Bond Angles

$\left(^{\circ}\right)$

$\begin{array}{lll}\mathrm{P}(1)-\mathrm{Ru}-\mathrm{P}(2) & 103.540(12) & 96.30(6) \\ \mathrm{X}-\mathrm{Ru}-\mathrm{P}(1) & 93.56(4)[\mathrm{X}=\mathrm{N}(1)] & 81.78(13)[\mathrm{X}=\mathrm{O}(1)] \\ \mathrm{O}(2)-\mathrm{Ru}-\mathrm{P}(1) & - & 105.38(14) \\ \mathrm{X}-\mathrm{Ru}-\mathrm{P}(2) & 84.87(3)[\mathrm{X}=\mathrm{N}(1)] & 83.86(14)[\mathrm{X}=\mathrm{O}(2)] \\ \mathrm{O}(1)-\mathrm{Ru}-\mathrm{P}(2) & - & 119.85(14) \\ \mathrm{O}(1)-\mathrm{Ru}-\mathrm{O}(2) & - & 41.13(18)\end{array}$

Other geo-

metrical

parameters

Ru-C5-ring $1.889 \quad 1.952$

$(\AA) \mathrm{a}$

$\begin{array}{lll}\Delta \mathrm{Ru}-\mathrm{C} & 0.132^{\mathrm{b}} & 0.204^{\mathrm{c}} \\ & 6.34^{\mathrm{o}} & 5.70^{\circ}\end{array}$

Fold angle $\quad 6.34^{\circ} \mathrm{d} \quad 5.70^{\circ} \mathrm{e}$

${ }^{a}$ Distance between the centroid of the C5 ring of the indenyl ligand and the ruthenium center.

${ }^{b}$ Average difference between the $\mathrm{Ru}-\mathrm{C} 2, \mathrm{Ru}-\mathrm{C} 3$ and $\mathrm{Ru}-\mathrm{C} 4$ bond lengths and the $\mathrm{Ru}-\mathrm{C} 1$ and $\mathrm{Ru}-\mathrm{C} 5$ bond lengths.

c Average difference between the Ru-C1, Ru-C2 and Ru-C3 and the Ru-C4 and Ru-C5 bond lengths, respectively.

$\mathrm{d}$ Angle between the plane formed by C2-C3-C4 and C1-C2-C4-C5.

e Angle between the plane formed by C1-C2-C3 and C1-C3-C4-C5. 
The X-ray structures demonstrate that in the presence of $\mathrm{NaPF}_{6}$ and $\mathrm{CH}_{3} \mathrm{CN}$, for $\left[\mathrm{RuCl}(\mathrm{ind})\left(\mathrm{PPh}_{3}\right)_{2}\right]$ the corresponding acetonitrile complex is obtained. As shown by X-ray and IR, it appears that $\mathrm{O}_{2}$ from air can replace the $\mathrm{CH}_{3} \mathrm{CN}$ ligand to give the corresponding $\eta^{2}-\mathrm{O}_{2}$ complex. However, when applied as catalysts in the title reaction under the conditions given in Table 3, only small reactivity or yield differences between $\left[\mathrm{Ru}(\mathrm{ind})\left(\mathrm{CH}_{3} \mathrm{CN}\right)\left(\mathrm{PPh}_{3}\right)_{2}\right] \mathrm{PF}_{6}$ and $\left[\mathrm{Ru}(\mathrm{ind})\left(\mathrm{CH}_{3} \mathrm{CN}\right)\left(\mathrm{PPh}_{3}\right)\left\{\mathrm{P}\left(p-\mathrm{C}_{6} \mathrm{H}_{4} \mathrm{CF}_{3}\right)_{3}\right\}\right] \mathrm{PF}_{6}$ and the in situ activated complexes were observed (Table 3, entry 5). We, thus, discontinued the investigation of preformed, isolated acetonitrile complex catalysts.

\subsection{Comparison of Catalytic Activity}

Finally, we speculated whether there were reactivity differences between the three complexes $\left[\mathrm{RuCl}(\right.$ ind $\left.)\left(\mathrm{PPh}_{3}\right)_{2}\right],\left[\mathrm{RuCl}(\right.$ ind $\left.)\left(\mathrm{PPh}_{3}\right)\left\{\mathrm{P}\left(p-\mathrm{C}_{6} \mathrm{H}_{4} \mathrm{CF}_{3}\right)_{3}\right\}\right]$ and $\left[\mathrm{RuCl}(\mathrm{ind})\left(\mathrm{PPh}_{3}\right)\left\{\mathrm{P}\left(3,5-\mathrm{C}_{6} \mathrm{H}_{3}\left(\mathrm{CF}_{3}\right)_{2}\right)_{3}\right\}\right]$. Accordingly, the three precursor complexes were activated by chloride abstraction for a test reaction; product formation was followed over time by NMR. The results are compiled in Figure 7. Somewhat surprisingly, all three precursor complexes gave comparable activities over time, i.e. product formation was comparable over time for the three complexes. This finding reflects the isolated yields for the catalysis products presented in Scheme 2, which are also fairly similar for the three complexes. 


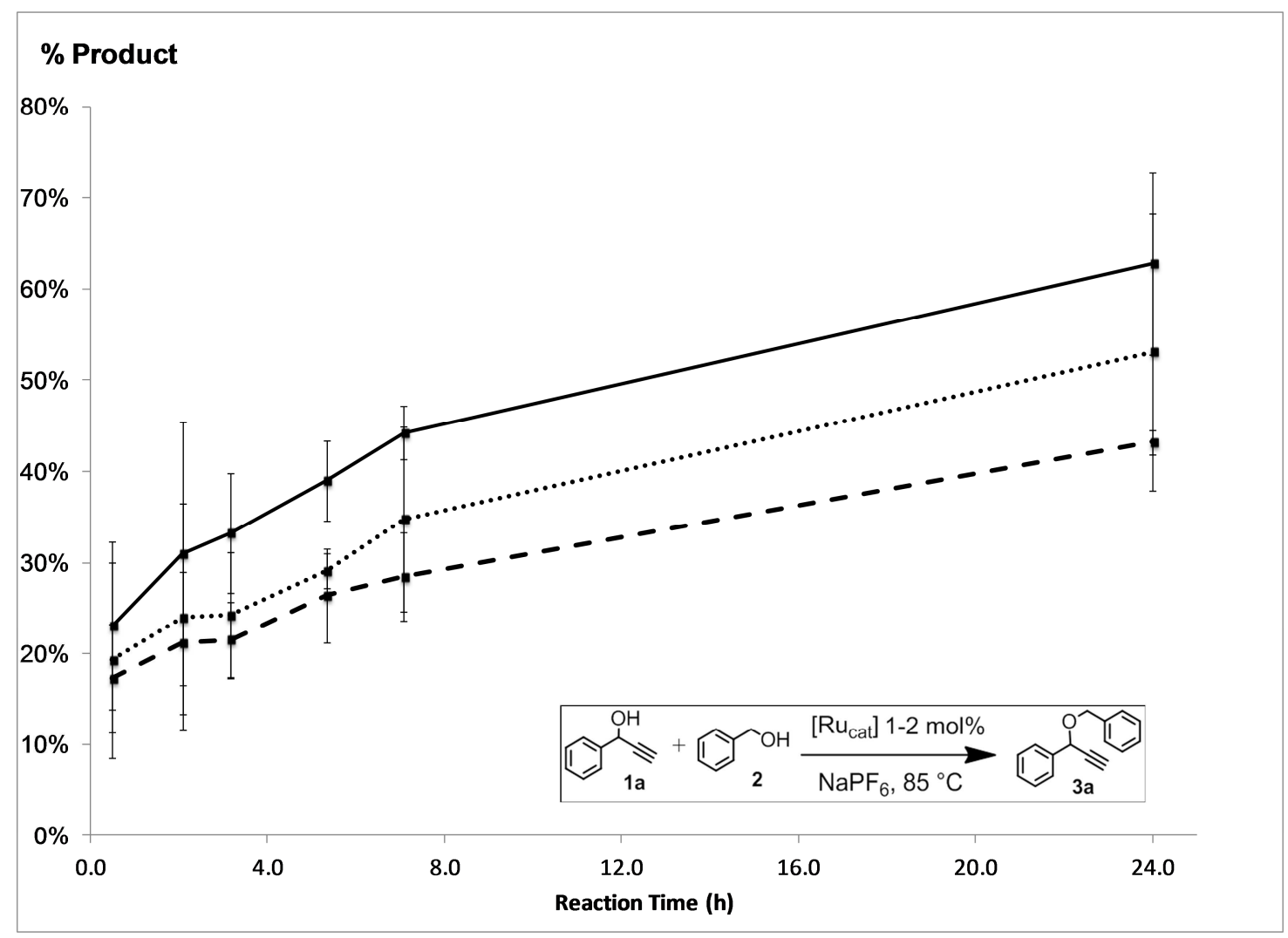

Figure 7. Activity comparison for the ruthenium complexes $\left[\mathrm{RuCl}(\mathrm{ind})\left(\mathrm{PPh}_{3}\right)\{\mathrm{P}(p\right.$ $\left.\left.\left.\mathrm{C}_{6} \mathrm{H}_{4} \mathrm{CF}_{3}\right)_{3}\right\}\right]$ (dotted line) and $\left[\mathrm{RuCl}(\mathrm{ind})\left(\mathrm{PPh}_{3}\right)\left\{\mathrm{P}\left(3,5-\mathrm{C}_{6} \mathrm{H}_{3}\left(\mathrm{CF}_{3}\right)_{2}\right)_{3}\right\}\right]$ (dashed) after activation by chloride abstraction. The average of three runs for each complex are shown and error bars are given. For comparison, the activity of $\left[\mathrm{RuCl}(\mathrm{ind})\left(\mathrm{PPh}_{3}\right)_{2}\right]$ (solid line) is also included.

While somewhat speculative, the similarities in reactivity point towards a common catalytically active species for all three catalysts appear to be involved. It is known from the literature that the $\mathrm{PF}_{6}{ }^{-}$anion can hydrolyze under aqueous conditions [31]. Thus, it cannot be excluded that hydrolysis products of the $\mathrm{PF}_{6}{ }^{-}$counter anion or other, common decomposition products of the precursor complexes contribute to the catalytic activity of the system. It appeared 
that the chemistry of mixed phosphine complexes of ruthenium of the general formula as in $\left[\mathrm{RuCl}(\right.$ ind $\left.)\left(\mathrm{PPh}_{3}\right)\left\{\mathrm{P}\left(p-\mathrm{C}_{6} \mathrm{H}_{4} \mathrm{CF}_{3}\right)_{3}\right\}\right]$ and $\left[\mathrm{RuCl}(\mathrm{ind})\left(\mathrm{PPh}_{3}\right)\left\{\mathrm{P}\left(3,5-\mathrm{C}_{6} \mathrm{H}_{3}\left(\mathrm{CF}_{3}\right)_{2}\right)_{3}\right\}\right]$ is more complex than we originally anticipated (as demonstrated in Figure 5). Further investigations of the catalytic system and about the catalytically active species are ongoing.

\section{Conclusion}

In conclusion, two new ruthenium complexes of the general formula $\left[\mathrm{RuCl}(\mathrm{ind})\left(\mathrm{PPh}_{3}\right) \mathrm{L}\right]$ were synthesized, bearing phosphine ligands $\mathrm{L}$ with $\mathrm{CF}_{3}$-substituted aryl rings . Structural characterization revealed that the geometry of the new complexes does not differ significantly from related complexes. However, the placement of the fluorinated ligands resulted in increased oxidation potentials compared to the parent complex $\left[\mathrm{RuCl}(\mathrm{ind})\left(\mathrm{PPh}_{3}\right)_{2}\right]$. The new complexes are, after activation through chloride abstraction, catalytically active in the etherification of

propargylic alcohols. As investigated through ${ }^{31} \mathrm{P}\left\{{ }^{1} \mathrm{H}\right\} \mathrm{NMR}$, the chloride abstracted fragments $\left[\mathrm{Ru}(\mathrm{ind})\left(\mathrm{PPh}_{3}\right) \mathrm{L}\right]^{+}$are not very stable and undergo a decomposition reaction in solution, and formation of the hydrido complex $\left[\mathrm{RuH}(\mathrm{ind})\left(\mathrm{PPh}_{3}\right)_{2}\right]$ was observed for the two precursor complexes, indicating ligand metathesis after chloride abstraction. When the catalytic activity of the new complexes [ RuCl(ind) $\left.\left(\mathrm{PPh}_{3}\right) \mathrm{L}\right]$ was determined for a test reaction and compared to the activity of the parent compound $\left[\mathrm{RuCl}(\mathrm{ind})\left(\mathrm{PPh}_{3}\right)_{2}\right]$, it appeared that all three complexes exhibited similar reactivities. Investigation of the catalytically active species is ongoing. 


\section{Experimental}

\subsection{General.}

All reactions were carried out under an inert $\mathrm{N}_{2}$ atmosphere using standard Schlenk techniques. The ligands tris(4-(trifluoromethyl)phenyl)phosphine, $\mathrm{P}\left(p-\mathrm{C}_{6} \mathrm{H}_{4} \mathrm{CF}_{3}\right)_{3}$, and tris(3,5bis(trifluoromethyl)phenyl)phosphine, $\mathrm{P}\left(3,5-\mathrm{C}_{6} \mathrm{H}_{3}\left(\mathrm{CF}_{3}\right)_{2}\right)_{3}$, were purchased from Strem Chemicals and used as is. All other chemicals, including $\mathrm{NaPF}_{6}$, were used as supplied from Sigma-Aldrich unless otherwise noted and used as received. The complex $\left[\mathrm{RuCl}(\mathrm{ind})\left(\mathrm{PPh}_{3}\right)_{2}\right]$ was synthesized following the literature [7]. THF was distilled from Na/benzophenone under $\mathrm{N}_{2}$. Ethyl acetate, hexane, toluene, $\mathrm{CH}_{2} \mathrm{Cl}_{2}$, and $\mathrm{ClCH}_{2} \mathrm{CH}_{2} \mathrm{Cl}$ were distilled prior to use; solvents used in catalysis were used as is.

\subsection{Instruments and measurements}

NMR spectra for characterization were collected at room temperature on a Varian Unity 300 MHz or Bruker Avance $300 \mathrm{MHz}$ instrument; all chemical shifts $(\boldsymbol{\delta})$ are reported in ppm and are referenced to a residual solvent signal. IR spectra were collected on a Thermo Nicolet 360 FT-IR spectrometer. FAB and exact mass data were collected on a JEOL MStation [JMS-700] Mass Spectrometer. Melting points were determined on a Thomas Hoover uni-melt capillary melting point apparatus and are uncorrected. Elemental analyses were performed by Atlantic Microlab Inc., Norcross, GA, USA.

\section{3. $\left[\mathrm{RuCl}(\mathrm{ind})\left(\mathrm{PPh}_{3}\right)\left\{\mathrm{P}\left(\mathrm{p}-\mathrm{C}_{6} \mathrm{H}_{4} \mathrm{CF}_{3}\right)_{3}\right\}\right]$}

A Schlenk flask containing [RuCl(ind) $\left.\left(\mathrm{PPh}_{3}\right)_{2}\right](0.260 \mathrm{~g}, 0.335 \mathrm{mmol}), \mathrm{P}\left(p-\mathrm{C}_{6} \mathrm{H}_{4} \mathrm{CF}_{3}\right)_{3}$ $(0.158 \mathrm{~g}, 0.339 \mathrm{mmol})$, and THF $(5 \mathrm{~mL})$ was refluxed gently for 4 hours under nitrogen. The 
solvent was removed via vacuum. The complex was isolated as a red solid $(0.148 \mathrm{~g}, 0.125 \mathrm{mmol}$, $57 \%$ ) by column chromatography, silica gel $(2 \times 10 \mathrm{~cm})$ using $\mathrm{CH}_{2} \mathrm{Cl}_{2}$ and petroleum ether (1:3) as eluent. The product was recrystallized from $\mathrm{CH}_{2} \mathrm{Cl}_{2}$ layered with hexanes. m.p. $122-124{ }^{\circ} \mathrm{C}$ (dec., capillary). ${ }^{1} \mathrm{H}$ NMR $\left(300 \mathrm{MHz}, \mathrm{CDCl}_{3}\right) \delta$ 7.40-7.29 (m, 24H, arom.), 7.20-7.11 (m, 6H, arom.), 6.92-6.81 (m, 2H, arom.), 4.73-4.70 (m, 1H, indenyl), 4.43 (br s, 1H, indenyl), 3.74 (s, 1H, indenyl); ${ }^{13} \mathrm{C}\left\{{ }^{1} \mathrm{H}\right\} \mathrm{NMR}\left(75 \mathrm{MHz}, \mathrm{CDCl}_{3}\right) \delta 140.7$ (s), 140.2 (s), 136.6 (s), $136.0(\mathrm{~s}), 134.2$ (s), 134.1 (s), 133.8 (s), 133.6 (s), 131.6 (s), 131.2 (s), 130.8 (s), 130.3 (s), 129.7 (s), 129.4 (s), 129.0 (s), 128.6 (s), 127.8 (s), 127.7 (s), 125.8 (s), 125.5 (s), 124.7 (m), 123.4 (s), 122.2 (s), 118.6 (s), 112.8 (s), 112.7 (s), 110.6 (br s), 89.6 (s), 70.9 (s), 70.8 (s), 64.8 (s), 53.7 (s, $\mathrm{CH}_{2} \mathrm{Cl}_{2}$ ), 31.8 (s, hexanes), 22.9 (s, hexanes), 14.4 (s, hexanes); ${ }^{31} \mathrm{P}\left\{{ }^{1} \mathrm{H}\right\} \mathrm{NMR}\left(121 \mathrm{MHz}, \mathrm{CDCl}_{3}\right) \delta 50.1$ $\left(\mathrm{d}, J_{\mathrm{PP}}=42 \mathrm{~Hz}\right), 44.2\left(\mathrm{~d}, J_{\mathrm{PP}}=42 \mathrm{~Hz}\right) ;{ }^{19} \mathrm{~F}\left\{{ }^{1} \mathrm{H}\right\} \mathrm{NMR}\left(282 \mathrm{MHz}, \mathrm{CDCl}_{3}\right) \delta-62.9 . \mathrm{IR}$ (neat, solid): $\tilde{\mathrm{v}}=3041$ (w), 2956 (w), 2923 (w), $1604(\mathrm{w}), 1479(\mathrm{w}), 1395$ (w), $1317(\mathrm{w}), 1162$ (w), $1113(\mathrm{w}), 1085$ (s), 1055 (s), 1012 (s), 842 (m), 823 (m), $778(\mathrm{~m}), 746(\mathrm{~m}) \mathrm{cm}^{-1}$. FAB-MS m/z (\%) $718(20)\left[\mathrm{RuCl}(\mathrm{ind})\left\{\mathrm{P}\left(p-\mathrm{C}_{6} \mathrm{H}_{4} \mathrm{CF}_{3}\right)_{3}\right\}\right]^{+}, 683$ (22) $\left[\mathrm{Ru}(\text { ind })\left\{\mathrm{P}\left(p-\mathrm{C}_{6} \mathrm{H}_{4} \mathrm{CF}_{3}\right)_{3}\right\}\right]^{+}, 483(32)$ $\left[\mathrm{O}=\mathrm{P}\left(p-\mathrm{C}_{6} \mathrm{H}_{4} \mathrm{CF}_{3}\right)_{3}\right]^{+}, 466(100)\left[\mathrm{P}\left(p-\mathrm{C}_{6} \mathrm{H}_{4} \mathrm{CF}_{3}\right)_{3}\right]^{+}, 321(15)\left[\mathrm{P}\left(p-\mathrm{C}_{6} \mathrm{H}_{4} \mathrm{CF}_{3}\right)_{2}\right]^{+}, 262(43)$ $\left[\mathrm{PPh}_{3}\right]^{+} . \mathrm{C}_{48} \mathrm{H}_{34} \mathrm{ClF}_{9} \mathrm{P}_{2} \mathrm{Ru}(980.24)$ : calcd. C 58.81, H 3.50; found C 59.19, H 3.89.

\section{4. $\left[\mathrm{RuCl}(\mathrm{ind})\left(\mathrm{PPh}_{3}\right)\left\{\mathrm{P}\left(3,5-\mathrm{C}_{6} \mathrm{H}_{3}\left(\mathrm{CF}_{3}\right)_{2}\right)_{3}\right\}\right]$}

A Schlenk flask containing [RuCl(ind) $\left.\left(\mathrm{PPh}_{3}\right)_{2}\right](0.171 \mathrm{~g}, 0.219 \mathrm{mmol}), \mathrm{P}(3,5-\mathrm{C} 6 \mathrm{H} 3(\mathrm{CF} 3) 2) 3$

$(0.165 \mathrm{~g}, 0.242 \mathrm{mmol})$, and THF $(5 \mathrm{~mL})$ was refluxed gently for 4 hours under nitrogen. The solvent was removed via vacuum. The complex was isolated as a red solid $(0.077 \mathrm{~g}, 0.079 \mathrm{mmol}$, $24 \%)$ by column chromatography, silica gel $(2 \times 10 \mathrm{~cm})$ using $\mathrm{CH}_{2} \mathrm{Cl}_{2}$ and petroluem ether $(1: 3$ / 
v:v) as eluent. The complex was recrystallized from $\mathrm{CH}_{2} \mathrm{Cl}_{2}$ layered with hexanes, mp 141-143 ${ }^{\circ} \mathrm{C}$ (dec., capillary). ${ }^{1} \mathrm{H}$ NMR $\left(300 \mathrm{MHz}, \mathrm{CDCl}_{3}\right.$ ) $\delta$ 7.89-7.85 (m, 9H, arom.), 7.39-7.27 (m, 10H, arom.), 7.19-7.14 (m, 6H, arom.), 6.95-6.92 (m, 1H, arom.), 6.59-6.55 (m, 2H, arom.), 5.15 (br s, $1 \mathrm{H}$, indenyl), $4.84\left(\mathrm{~m}, 1 \mathrm{H}\right.$, indenyl), $3.82\left(\mathrm{~s}, 1 \mathrm{H}\right.$, indenyl) $;{ }^{13} \mathrm{C}\left\{{ }^{1} \mathrm{H}\right\} \mathrm{NMR}\left(75 \mathrm{MHz}, \mathrm{CDCl}_{3}\right) \delta$ $138.3(\mathrm{~s}), 137.8(\mathrm{~s}), 136.5(\mathrm{~s}), 135.9(\mathrm{~s}), 133.5\left(\mathrm{~d}, J_{\mathrm{CP}}=9.7 \mathrm{~Hz}\right), 133.3(\mathrm{~m}), 131.8\left(\mathrm{~d}, J_{\mathrm{CP}}=9.1\right.$ $\mathrm{Hz}), 131.4\left(\mathrm{~d}, J_{\mathrm{CP}}=9.1 \mathrm{~Hz}\right), 129.9(\mathrm{~s}), 129.3(\mathrm{~s}), 128.0\left(\mathrm{~d}, J_{\mathrm{CP}}=9.7 \mathrm{~Hz}\right), 126.7(\mathrm{~s}), 124.8(\mathrm{~s})$, 123.9 (s), 121.1 (s), 111.0 (s), 109.4 (s), 91.9 (s), 75.9 (s), 75.8 (s), 63.3 (s), $53.7\left(\mathrm{~s}, \mathrm{CH}_{2} \mathrm{Cl}_{2}\right)$; ${ }^{31} \mathrm{P}\left\{{ }^{1} \mathrm{H}\right\} \operatorname{NMR}\left(121 \mathrm{MHz}, \mathrm{CDCl}_{3}\right) \delta 50.1\left(\mathrm{~d}, J_{\mathrm{PP}}=42 \mathrm{~Hz}\right), 47.8\left(\mathrm{~d}, J_{\mathrm{PP}}=42 \mathrm{~Hz}\right) ;{ }^{19} \mathrm{~F}\left\{{ }^{1} \mathrm{H}\right\} \mathrm{NMR}$ $\left(282 \mathrm{MHz}, \mathrm{CDCl}_{3}\right) \delta-62.8$. IR (neat, solid): $\tilde{\mathrm{v}}=3053(\mathrm{w}), 3022(\mathrm{w}), 2308(\mathrm{w}), 2117(\mathrm{w}), 1888$ (w), $1821(w), 1614(w), 1478(w), 1432(w), 1351(\mathrm{~s}), 1275(\mathrm{~s}), 1176(\mathrm{~m}), 1117(\mathrm{~s}), 1088(\mathrm{~s})$, $893(\mathrm{~m}), 843(\mathrm{~m}), 816(\mathrm{~m}), 748(\mathrm{~m}) \mathrm{cm}^{-1}$. HRMS: calcd. for $\mathrm{C}_{51} \mathrm{H}_{31} \mathrm{~F}_{18} \mathrm{P}_{2}{ }^{102} \mathrm{Ru}$ 1149.0657; found 1149.047. $\mathrm{C}_{51} \mathrm{H}_{31} \mathrm{ClF}_{18} \mathrm{P}_{2} \mathrm{Ru}$ (1184.23): calcd. C 51.73, $\mathrm{H}$ 2.64; found $\mathrm{C}$ 50.72, $\mathrm{H} 2.70$.

\section{5. [Ru(ind $\left.)\left(\mathrm{CH}_{3} \mathrm{CN}\right)\left(\mathrm{PPh}_{3}\right)_{2}\right] P F_{6}$}

A Schlenk flask containing $\left[\mathrm{RuCl}(\mathrm{ind})\left(\mathrm{PPh}_{3}\right)_{2}\right](0.311 \mathrm{~g}, 0.401 \mathrm{mmol}), \mathrm{NaPF}_{6}(0.070 \mathrm{~g}, 0.417$ $\mathrm{mmol}), \mathrm{CH}_{3} \mathrm{CN}(0.200 \mathrm{~mL}, 3.829 \mathrm{mmol})$, and $\mathrm{MeOH}(15 \mathrm{~mL})$ was refluxed gently for 4 hours under nitrogen. An orange precipitate formed. The precipitate was isolated by vacuum filtration and dried under high vacuum to give the product as an orange solid $(0.230 \mathrm{~g}, 0.248 \mathrm{mmol}, 62$ \%). ${ }^{1} \mathrm{H}$ NMR (300 MHz, $\mathrm{CDCl}_{3}$ ) $\delta$ 7.29-7.21 (m, 20H, arom.), 7.18-7.12 (m, 14H, arom.), 6.88$6.80\left(\mathrm{~m}, 14 \mathrm{H}\right.$, arom.), 4.66 (br s, 1H, indenyl), 4.42 (s, $2 \mathrm{H}$, indenyl), 2.12 (s, $3 \mathrm{H}, \mathrm{CH}_{3} \mathrm{CN}$ ); ${ }^{31} \mathrm{P}\left\{{ }^{1} \mathrm{H}\right\} \mathrm{NMR}\left(121 \mathrm{MHz}, \mathrm{CDCl}_{3}\right) \delta 47.7$ (s), -146.0 (septet, $J_{\mathrm{FP}}=712 \mathrm{~Hz}, \mathrm{PF}_{6}{ }^{-}$). IR (neat, solid): $\tilde{v}=3637(w), 3322(w), 3049(w), 2278(w), 1626(w), 1582(w), 1531(w), 1478(m)$, 
$1431(\mathrm{~m}), 1329(\mathrm{w}), 1187(\mathrm{w}), 1156(\mathrm{w}), 1088(\mathrm{w}), 1026(\mathrm{w}), 996(\mathrm{w}), 829(\mathrm{~s}), 755(\mathrm{~s}), 746(\mathrm{~s})$ $\mathrm{cm}^{-1}$. FAB-MS m/z (\%) $741(80)\left[\mathrm{Ru}(\text { ind })\left(\mathrm{PPh}_{3}\right)_{2}\right]^{+}, 479(100)\left[\mathrm{Ru}(\text { ind })\left(\mathrm{PPh}_{3}\right)\right]^{+}$. ESI-MS $m / z$ (\%) $782(20)\left[\mathrm{Ru}(\text { ind })\left(\mathrm{CH}_{3} \mathrm{CN}\right)\left(\mathrm{PPh}_{3}\right)_{2}\right]^{+}, 741$ (100) $\left[\mathrm{Ru}(\mathrm{ind})\left(\mathrm{PPh}_{3}\right)_{2}\right]^{+}$.

\section{6. $\left[\mathrm{Ru}(\right.$ ind $\left.)\left(\mathrm{CH}_{3} \mathrm{CN}\right)\left(\mathrm{PPh}_{3}\right)\left\{\mathrm{P}\left(\mathrm{p}-\mathrm{C}_{6} \mathrm{H}_{4} \mathrm{CF}_{3}\right)_{3}\right\}\right] P \mathrm{~F}_{6}$}

A Schlenk flask containing $\left[\mathrm{RuCl}(\mathrm{ind})\left(\mathrm{PPh}_{3}\right)\left\{\mathrm{P}\left(p-\mathrm{C}_{6} \mathrm{H}_{4} \mathrm{CF}_{3}\right)_{3}\right\}\right](0.042 \mathrm{~g}, 0.043 \mathrm{mmol})$, $\mathrm{NaPF}_{6}(0.008 \mathrm{~g}, 0.050 \mathrm{mmol}), \mathrm{CH}_{3} \mathrm{CN}(0.200 \mathrm{~mL}, 3.829 \mathrm{mmol})$, and $\mathrm{MeOH}(10 \mathrm{~mL})$ was stirred at room temperature for 1.5 hours under nitrogen. The solvent was removed and solids were washed with diethyl ether and dried. The residue was passed through a cotton-filled pipette using chloroform. The residue was dried and the product was isolated as a yellow-orange solid (0.034 g, $0.030 \mathrm{mmol}, 69.9 \%) .{ }^{1} \mathrm{H} \mathrm{NMR}\left(300 \mathrm{MHz}, \mathrm{CDCl}_{3}\right) \delta$ 7.29-7.21 (m, 20H, arom.), 7.18-7.12 (m, 14H, arom.), 6.88-6.80 (m, 14H, arom.), 4.66 (br s, 1H, indenyl), 4.42 (s, 2H, indenyl), 2.12 $\left(\mathrm{s}, 3 \mathrm{H}, \mathrm{CH}_{3} \mathrm{CN}\right) ;{ }^{31} \mathrm{P}\left\{{ }^{1} \mathrm{H}\right\} \mathrm{NMR}\left(121 \mathrm{MHz}, \mathrm{CDCl}_{3}\right) \delta 49.5\left(\mathrm{~d}, J_{\mathrm{PP}}=35 \mathrm{~Hz}\right), 47.4\left(\mathrm{~d}, J_{\mathrm{PP}}=35 \mathrm{~Hz}\right)$, -141.0 (septet, $J_{\mathrm{FP}}=712 \mathrm{~Hz}, \mathrm{PF}_{6}^{-}$). IR (neat, solid): $\tilde{\mathrm{v}}=3069(\mathrm{w}), 2930(\mathrm{w}), 2864(\mathrm{w}), 2320(\mathrm{w})$, $1604(w), 1478(w), 1433(w), 1394(w), 1318$ (s), 1165 (m), $1120($ s), 1088 (m), $1056(\mathrm{~s}), 1012$ (m), 824 (s), 745 (m). FAB-MS m/z (\%) 945 (70) $\left[\mathrm{Ru}(\mathrm{ind})\left\{\mathrm{P}\left(p-\mathrm{C}_{6} \mathrm{H}_{4} \mathrm{CF}_{3}\right)_{3}\right\}\left(\mathrm{PPh}_{3}\right)\right]^{+}, 683(40)$ $\left[\mathrm{Ru}(\text { ind })\left\{\mathrm{P}\left(p-\mathrm{C}_{6} \mathrm{H}_{4} \mathrm{CF}_{3}\right)_{3}\right\}\right]^{+}, 479(100)\left[\mathrm{Ru}(\mathrm{ind})\left(\mathrm{PPh}_{3}\right)\right]^{+}$. ESI-MS m/z (\%) 986 (25) $\left[\mathrm{Ru}(\text { ind })\left(\mathrm{CH}_{3} \mathrm{CN}\right)\left(\mathrm{PPh}_{3}\right)\left\{\mathrm{P}\left(p-\mathrm{C}_{6} \mathrm{H}_{4} \mathrm{CF}_{3}\right)_{3}\right\}\right]^{+}, 945(100)\left[\mathrm{Ru}(\operatorname{Indenyl})\left(\mathrm{PPh}_{3}\right)\left(\mathrm{P}\left(\mathrm{ArCF}_{3}\right)_{3}\right)\right]^{+}$.

\section{7. $\left[\mathrm{Ru}(\mathrm{ind})\left(\eta^{2}-\mathrm{O}_{2}\right)\left(P P h_{3}\right)_{2}\right] P F_{6}$}

A NMR tube containing $\left[\mathrm{Ru}(\mathrm{ind})\left(\mathrm{CH}_{3} \mathrm{CN}\right)\left(\mathrm{PPh}_{3}\right)_{2}\right] \mathrm{PF}_{6}$ in $\mathrm{CDCl}_{3}$ was allowed to rest on the bench top for 72 hours, over which dark solid crystals deposited. IR (neat, solid): $\tilde{v}=3056$ (w), 
$2920(\mathrm{~m}), 2850(\mathrm{w}), 2283(\mathrm{w}), 1479(\mathrm{~m}), 1432(\mathrm{~m}), 1186(\mathrm{w}), 1087(\mathrm{~m}), 996(\mathrm{w}), 909(\mathrm{~m}), 828$

$\left(\mathrm{s}, \eta^{2}-\mathrm{O}_{2}\right), 723(\mathrm{~s}) \mathrm{cm}^{-1}$. From X-ray sample (in Nujol): FAB-MS $m / z(\%) 741$ (52)

[Ru(ind) $\left.\left(\mathrm{PPh}_{3}\right)_{2}\right]^{+}, 625(10)\left[\mathrm{Ru}\left(\mathrm{PPh}_{3}\right)_{2}\right]^{+}, 479(100)\left[\mathrm{Ru}(\mathrm{ind})\left(\mathrm{PPh}_{3}\right)\right]^{+}, 363(16)\left[\mathrm{Ru}\left(\mathrm{PPh}_{3}\right)\right]$,

279 (64) $\left[\mathrm{O}=\mathrm{PPh}_{3}\right]$. From separate crystal: ESI-MS m/z (\%) $782\left[\mathrm{Ru}(\mathrm{ind})\left(\mathrm{CH}_{3} \mathrm{CN}\right)\left(\mathrm{PPh}_{3}\right)_{2}\right]^{+}$,

$\left.741\left[\mathrm{Ru}(\mathrm{ind})\left(\mathrm{PPh}_{3}\right)_{2}\right)\right]^{+}$.

\subsection{Catalysis}

Unless otherwise indicated, the ruthenium complexes were placed into a screw-capped vial containing $1 \mathrm{~mL}$ of acetonitrile in toluene (1 MeCN: $9 \mathrm{Tol})$, and $\mathrm{NaPF}_{6}(4$ molar equivalents with respect to ruthenium), and heated for approximately 20 minutes. To this solution, the propargyl alcohol and substituent nucleophile were added and allowed to heat for the remainder of the reaction time.

\subsection{Activity determinations in Figure 7}

The respective precursor complex $(0.0061 \mathrm{mmol}, 2 \mathrm{~mol} \%)$ was placed into an NMR tube along with $\mathrm{NaPF}_{6}(0.006 \mathrm{~g}, 0.036 \mathrm{mmol})$ and $\mathrm{CH}_{3} \mathrm{CN}(0.02 \mathrm{~mL})$. The mixture was heated for 5 minutes at $85{ }^{\circ} \mathrm{C}$. A solution containing 1-phenyl-2-propyn-1-ol (1a, $\left.0.041 \mathrm{~g}, 0.31 \mathrm{mmol}\right)$, benzyl alcohol (2b, $42 \mathrm{mg}, 0.39 \mathrm{mmol}$ ) and $p$-dimethoxybenzene (internal standard, $0.002 \mathrm{~g}$ ) in toluene- $\mathrm{d}_{8}(0.6 \mathrm{~mL})$ was added to each NMR tube. The mixture was heated at $85{ }^{\circ} \mathrm{C}$ for 24

hours, where ${ }^{1} \mathrm{H}$ NMR spectra were recorded for each reaction mixture over a consistent time period. Integration of the diastereotopic doublets at $\delta 4.78\left(\mathrm{~d}, \mathrm{~J}_{\mathrm{HH}}=11.7 \mathrm{~Hz}, \mathrm{CH}_{2}, 2 \mathrm{H}\right)$ for the 
product in the spectrum were referenced to the aromatic protons of $p$-dimethoxybenzene at $\delta$ $6.71(4 \mathrm{H})$.

\subsection{Cyclic Voltammetry}

Voltammograms were recorded in a three-electrode BAS electrochemical cell in a Vacuum Atmospheres HE-493 drybox under an atmosphere of argon in $0.1 \mathrm{M} \mathrm{NBu}_{4} \mathrm{PF}_{6} / \mathrm{CH}_{2} \mathrm{Cl}_{2}$ at 298 K. A $1.6 \mathrm{~mm}$ Pt disk electrode was used as the working electrode, a platinum wire was used as the auxiliary electrode, and a silver wire was used a pseudo-reference electrode. Potentials were calibrated against the $\mathrm{Cp}^{*}{ }_{2} \mathrm{Fe}^{0 /+}$ couple, which is known to occur at $-0.548 \mathrm{~V}$ vs the $\mathrm{Cp}_{2} \mathrm{Fe}^{0 /+}$ couple for this solvent medium [32]. The potentials in this paper can be changed to SCE reference values by addition of $0.56 \mathrm{~V}$. Voltammograms were collected at $0.05-1.6 \mathrm{~V} / \mathrm{s}$ with an EG\&G PAR 263A potentiostat interfaced to a computer operated with EG\&G PAR Model 270 software.

\subsection{X-ray Structure Determination for [RuCl(ind) $\left.\left(P P h_{3}\right)\left\{P\left(p-C_{6} H_{4} C F_{3}\right)_{3}\right\}\right]$,}

$\left.\left[\mathrm{RuCl}(\mathrm{ind})\left(\mathrm{PPh}_{3}\right)\left\{\mathrm{P}\left(3,5-\mathrm{C}_{6} \mathrm{H}_{3}\left(\mathrm{CF}_{3}\right)_{2}\right)_{3}\right\}\right],\left[\mathrm{Ru}(\mathrm{ind})\left(\mathrm{CH}_{3} \mathrm{CN}\right)\left(\mathrm{PPh}_{3}\right)_{2}\right)\right] P F_{6}$ and $\left[\mathrm{Ru}(\mathrm{ind})\left(\eta^{2}\right.\right.$ $\left.\left.\mathrm{O}_{2}\right)\left(P P h_{3}\right)_{2}\right] P F_{6}$

Crystals of $\left[\mathrm{RuCl}(\right.$ ind $\left.)\left(\mathrm{PPh}_{3}\right)\left\{\mathrm{P}\left(p-\mathrm{C}_{6} \mathrm{H}_{4} \mathrm{CF}_{3}\right)_{3}\right\}\right],\left[\mathrm{RuCl}(\mathrm{ind})\left(\mathrm{PPh}_{3}\right)\{\mathrm{P}(3,5-\right.$ $\left.\left.\left.\mathrm{C}_{6} \mathrm{H}_{3}\left(\mathrm{CF}_{3}\right)_{2}\right)_{3}\right\}\right]$, $\left[\mathrm{Ru}(\right.$ ind $\left.\left.)\left(\mathrm{CH}_{3} \mathrm{CN}\right)\left(\mathrm{PPh}_{3}\right)_{2}\right)\right] \mathrm{PF}_{6}$ of appropriate dimension were obtained by diffusion of $\mathrm{CH}_{2} \mathrm{Cl}_{2}$ into hexane solutions of the complexes. Crystals of $\left[\mathrm{Ru}(\mathrm{ind})\left(\eta^{2}-\right.\right.$ $\left.\left.\mathrm{O}_{2}\right)\left(\mathrm{PPh}_{3}\right)_{2}\right] \mathrm{PF}_{6}$ were obtained by storage of a $\mathrm{CDCl}_{3}$ solution of $\left.\left[\mathrm{Ru}(\mathrm{ind})\left(\mathrm{CH}_{3} \mathrm{CN}\right)\left(\mathrm{PPh}_{3}\right)_{2}\right)\right] \mathrm{PF}_{6}$ under aerobic conditions and directly taken from the reaction mixture. Crystals of approximate 
dimensions were mounted on MiTeGen cryoloops in random orientations. Preliminary examination and data collection were performed using a Bruker X8 Kappa Apex II Charge Coupled Device (CCD) Detector system single crystal X-ray diffractometer equipped with an Oxford Cryostream LT device. All data were collected using graphite monochromated Mo Ka radiation $(\lambda=0.71073 \AA)$ from a fine focus sealed tube X-ray source. Preliminary unit cell constants were determined with a set of 36 narrow frame scans. Typical data sets consist of combinations of $\omega$ and $\Phi$ scan frames with typical scan width of $0.5^{\circ}$ and counting time of 15 seconds/frame at a crystal to detector distance of $4.0 \mathrm{~cm}$. The collected frames were integrated using an orientation matrix determined from the narrow frame scans. Apex II and SAINT software packages [33] were used for data collection and data integration. Analysis of the integrated data did not show any decay. Final cell constants were determined by global refinement of reflections harvested from the complete data set. Collected data were corrected for systematic errors using SADABS [33] based on the Laue symmetry using equivalent reflections.

Crystal data and intensity data collection parameters are listed in Table 4.

Structure solution and refinement were carried out using the SHELXTL- PLUS software package [34]. The structures were solved and refined successfully in the space groups $\mathrm{P} 2{ }_{1}$ for $\left[\mathrm{Ru}(\right.$ ind $\left.\left.)\left(\mathrm{CH}_{3} \mathrm{CN}\right)\left(\mathrm{PPh}_{3}\right)_{2}\right)\right] \mathrm{PF}_{6}$ and $\mathrm{P}-1$ for all other complexes. Full matrix least-squares refinements were carried out by minimizing $\Sigma \mathrm{w}\left(\mathrm{F}_{\mathrm{o}}{ }^{2}-\mathrm{F}_{\mathrm{c}}{ }^{2}\right)^{2}$. The non-hydrogen atoms were refined anisotropically to convergence. All hydrogen atoms were treated using appropriate riding model (AFIX m3). The final residual values and structure refinement parameters are listed in Table 4. 
Table 4. Crystallographic Parameters

\begin{tabular}{|c|c|c|c|c|}
\hline & $\begin{array}{l}{\left[\mathrm{RuCl}(\text { ind })\left(\mathrm{PPh}_{3}\right)\{\mathrm{P}(p-\right.} \\
\left.\left.\left.\mathrm{C}_{6} \mathrm{H}_{4} \mathrm{CF}_{3}\right)_{3}\right\}\right]\end{array}$ & $\begin{array}{l}{\left[\mathrm{RuCl}(\mathrm{ind})\left(\mathrm{PPh}_{3}\right)\right.} \\
\{\mathrm{P}(3,5- \\
\left.\left.\left.\mathrm{C}_{6} \mathrm{H}_{3}\left(\mathrm{CF}_{3}\right)_{2}\right)_{3}\right\}\right]\end{array}$ & $\begin{array}{l}{\left[\mathrm{Ru}(\mathrm{ind})\left(\mathrm{CH}_{3} \mathrm{CN}\right)\right.} \\
\left.\left(\mathrm{PPh}_{3}\right)_{2}\right] \mathrm{PF}_{6}\end{array}$ & $\begin{array}{l}{\left[\mathrm{Ru}(\text { ind })\left(\mathrm{n}^{2}-\mathrm{O}_{2}\right)\right.} \\
\left.\left(\mathrm{PPh}_{3}\right)_{2}\right] \mathrm{PF}_{6}\end{array}$ \\
\hline Empirical formula & $\begin{array}{l}\left(\mathrm{C}_{48} \mathrm{H}_{34} \mathrm{ClF}_{9} \mathrm{P}_{2} \mathrm{Ru}\right)_{2} \\
\left(\mathrm{CHCl}_{3}\right)_{3}\end{array}$ & $\begin{array}{l}\left(\mathrm{C}_{51} \mathrm{H}_{31} \mathrm{ClF}_{18} \mathrm{P}_{2} \mathrm{Ru}\right)_{2} \\
\mathrm{Et}_{2} \mathrm{O}\end{array}$ & $\mathrm{C}_{47} \mathrm{H}_{40} \mathrm{~F}_{6} \mathrm{NP}_{3} \mathrm{Ru}$ & $\mathrm{C}_{45} \mathrm{H}_{37} \mathrm{~F}_{6} \mathrm{O}_{2} \mathrm{P}_{3} \mathrm{Ru}$ \\
\hline Formula weight & 2318.52 & 2456.54 & 926.78 & 917.72 \\
\hline $\begin{array}{l}\text { Temperature K / } \\
\text { Wavelength } \AA\end{array}$ & $100(2) / 0.71073$ & $100(2) / 0.71073$ & $100(2) / 0.71073$ & $100(2) \mathrm{K} / 0.71073$ \\
\hline Crystal system & Triclinic & Triclinic & Monoclinic & Triclinic \\
\hline Space group & $P-1$ & $\mathrm{P}-1$ & $\mathrm{P} 2_{1}$ & $\mathrm{P}-1$ \\
\hline $\begin{array}{l}\text { Unit cell } \\
\text { dimensions }\end{array}$ & $\begin{array}{l}a=9.5521(3) \AA \\
b=11.5438(4) \AA \\
c=21.3297(8) \AA \\
\alpha=90.0613(19)^{\circ} \\
\beta=90.123(2)^{\circ} \\
\gamma=90.9485(18)^{\circ}\end{array}$ & $\begin{array}{l}a=11.3198(4) \AA \\
b=20.1160(10) \AA \\
c=22.2959(10) \AA \\
\alpha=101.841(2)^{\circ} \\
\beta=93.1865(18)^{\circ} \\
\gamma=94.4486(19)^{\circ}\end{array}$ & $\begin{array}{l}a=10.5101(13) \AA \\
b=17.3270(19) \AA \\
c=11.2487(13) \AA \\
\alpha=90^{\circ} \\
\beta=96.677(7)^{\circ} \\
\gamma=90^{\circ}\end{array}$ & $\begin{array}{l}a=9.8032(5) \AA \\
b=14.8889(8) \AA \\
c=19.5349(10) \AA \\
\alpha=72.190(3)^{\circ} \\
\beta=79.428(3)^{\circ} \\
\gamma=71.868(3)^{\circ}\end{array}$ \\
\hline Volume / Z & $2351.64(14) \AA^{3} / 1$ & $4940.7(4) \AA^{3} / 2$ & $2034.6(4) \AA^{3} / 2$ & $2567.5(2) \AA^{3} / 2$ \\
\hline $\begin{array}{l}\text { Density } \\
\text { (calculated) }\end{array}$ & $1.637 \mathrm{Mg} / \mathrm{m}^{3}$ & $1.651 \mathrm{Mg} / \mathrm{m}^{3}$ & $1.531 \mathrm{Mg} / \mathrm{m}^{3}$ & $1.187 \mathrm{Mg} / \mathrm{m}^{3}$ \\
\hline $\begin{array}{l}\text { Absorption } \\
\text { coefficient }\end{array}$ & $0.786 \mathrm{~mm}^{-1}$ & $0.545 \mathrm{~mm}^{-1}$ & $0.567 \mathrm{~mm}^{-1}$ & $0.451 \mathrm{~mm}^{-1}$ \\
\hline$F(000)$ & 1162 & 2456 & 944 & 932 \\
\hline $\begin{array}{l}\text { Crystal size / } \\
\mathrm{mm}^{3}\end{array}$ & $0499 \times 0348 \times 0337$ & $0406 \times 0337 \times 0189$ & $0598 \times 0365 \times 0219$ & $0384 \times 0199 \times 0107$ \\
\hline $\begin{array}{l}\text { Theta range for } \\
\text { data collection }\end{array}$ & 1.764 to $37.238^{\circ}$ & 0.936 to $27.799^{\circ}$ & 1.823 to $40.516^{\circ}$ & 1.100 to $26.492^{\circ}$ \\
\hline Index ranges & $\begin{array}{l}-16 \leq h \leq 16 \\
-17 \leq k \leq 19 \\
-36 \leq 1 \leq 36\end{array}$ & $\begin{array}{l}-14 \leq h \leq 14 \\
-26 \leq k \leq 25 \\
0 \leq 1 \leq 29\end{array}$ & $\begin{array}{l}-18 \leq h \leq 19 \\
-28 \leq k \leq 30 \\
-20 \leq 1 \leq 19\end{array}$ & $\begin{array}{l}-9 \leq h \leq 12 \\
-18 \leq k \leq 18 \\
-24 \leq 1 \leq 24\end{array}$ \\
\hline $\begin{array}{l}\text { Reflections } \\
\text { collected }\end{array}$ & 59057 & 22976 & 92778 & 39837 \\
\hline $\begin{array}{l}\text { Independent } \\
\text { reflections }\end{array}$ & $59057[\mathrm{R}$ (int) $=0.018]$ & $22976[R($ int $)=0.042]$ & $24235[\mathrm{R}$ (int) $=0.028]$ & $10242[R($ int $)=0.070]$ \\
\hline $\begin{array}{l}\text { Absorption } \\
\text { correction }\end{array}$ & $\begin{array}{l}\text { Semi-empirical from } \\
\text { equivalents }\end{array}$ & $\begin{array}{l}\text { Semi-empirical from } \\
\text { equivalents }\end{array}$ & $\begin{array}{l}\text { Semi-empirical from } \\
\text { equivalents }\end{array}$ & $\begin{array}{l}\text { Semi-empirical from } \\
\text { equivalents }\end{array}$ \\
\hline $\begin{array}{l}\text { Max. and min. } \\
\text { transmission }\end{array}$ & 0.791035 and 0.737117 & $\begin{array}{l}0.862066 \text { and } \\
0.748420\end{array}$ & 0.7693 and 0.7103 & 0.7672 and 0.6547 \\
\hline $\begin{array}{l}\text { Data / restraints / } \\
\text { parameters }\end{array}$ & 59057 / 37 / 624 & 22976 / 343 / 1392 & $24235 / 1 / 523$ & 10242 / 73 / 545 \\
\hline $\begin{array}{l}\text { Goodness-of-fit } \\
\text { on F2 }\end{array}$ & 1.058 & 1.011 & 1.053 & 1.044 \\
\hline $\begin{array}{l}\text { Final } R \text { indices } \\
{[\mid>2 \text { sigma }(I)]}\end{array}$ & $\mathrm{R} 1=0.0497$ & $R 1=0.0499$ & $\mathrm{R} 1=0.0236$ & $\mathrm{R} 1=0.0788$ \\
\hline $\begin{array}{l}R \text { indices (all } \\
\text { data) }\end{array}$ & $w R 2=0.1341$ & $w R 2=0.1289$ & $w R 2=0.0530$ & $w R 2=0.1803$ \\
\hline $\begin{array}{l}\text { Largest diff. peak } \\
\text { and hole / e. } \AA^{-3}\end{array}$ & 2.245 and -1.603 & 1.617 and -0.837 & 0.763 and -0.551 & 1.356 and -1.905 \\
\hline
\end{tabular}


Absolute structure determination was carried out using Parson's method [35] for $\left[\mathrm{Ru}(\right.$ ind $\left.\left.)\left(\mathrm{CH}_{3} \mathrm{CN}\right)\left(\mathrm{PPh}_{3}\right)_{2}\right)\right] \mathrm{PF}_{6}$ with Flack $\mathrm{x}=-0.021(4)$ from 10263 selected quotients.

For the compound $\left[\mathrm{Ru}(\mathrm{ind})\left(\eta^{2}-\mathrm{O}_{2}\right)\left(\mathrm{PPh}_{3}\right)_{2}\right] \mathrm{PF}_{6}$ Platon-Squeeze [36] was used to remove badly disordered solvent molecules $\left(3 \times \mathrm{CHCl}_{3}\right)$ The counter ion $\mathrm{PF}_{6}$ is also disordered and the disorder was resolved with partial occupancy $\mathrm{F}$ atoms with geometrical restraints.

For the complex $\left[\mathrm{RuCl}(\mathrm{ind})\left(\mathrm{PPh}_{3}\right)\left\{\mathrm{P}\left(p-\mathrm{C}_{6} \mathrm{H}_{4} \mathrm{CF}_{3}\right)_{3}\right\}\right]$, half a molecule of ethylacetate was found in the lattice. Two $\mathrm{CF}_{3}$ groups and the $\mathrm{CH}_{3}$ of the solvent were disordered. The disorder was modeled with partial occupancy atoms and geometrical restraints.

The data for $\left[\mathrm{RuCl}(\mathrm{ind})\left(\mathrm{PPh}_{3}\right)\left\{\mathrm{P}\left(3,5-\mathrm{C}_{6} \mathrm{H}_{3}\left(\mathrm{CF}_{3}\right)_{2}\right)_{3}\right\}\right]$ was twinned. A two component twin model was used for refinement with $\mathrm{BASF}=0.49 .1 .5$ molecules of $\mathrm{CHCl}_{3} / \mathrm{Ru}$ were found in the lattice. Disordered $\mathrm{CF}_{3}$ group was refined with partial occupancy $\mathrm{F}$ atoms with geometrical restraints.

Tables of calculated and observed structure factors are available in electronic format.

\section{Appendix A. Supplementary data.}

Crystallographic data for the structural analysis has been deposited with the Cambridge Crystallographic Data Centre, CCDC No. 1518190 for complex $\left[\mathrm{RuCl}(\mathrm{ind})\left(\mathrm{PPh}_{3}\right)\{\mathrm{P}(p\right.$ C6H4CF3)3 $\}$, CCDC No. 1518189 for complex [RuCl(ind) $\left.\left(\mathrm{PPh}_{3}\right)\{\mathrm{P}(3,5-\mathrm{C} 6 \mathrm{H} 3(\mathrm{CF} 3) 2) 3\}\right]$, CCDC No. 1518188 for complex $\left[\mathrm{Ru}(\right.$ ind $\left.\left.)\left(\mathrm{CH}_{3} \mathrm{CN}\right)\left(\mathrm{PPh}_{3}\right)_{2}\right)\right] \mathrm{PF}_{6}$ and CCDC No. 1518187 for complex $\left[\mathrm{Ru}(\mathrm{ind})\left(\eta^{2}-\mathrm{O}_{2}\right)\left(\mathrm{PPh}_{3}\right)_{2}\right] \mathrm{PF}_{6}$. Copies of this information may be obtained free of charge via http://www.ccdc.cam.ac.uk. Supplementary data [experimental details for the known catalysis products in Scheme 2, NMR spectra $\left({ }^{1} \mathrm{H},{ }^{13} \mathrm{C}\left\{{ }^{1} \mathrm{H}\right\},{ }^{31} \mathrm{P}\left\{{ }^{1} \mathrm{H}\right\}\right)$ for the metal complexes 
[RuCl(ind) $\left.\left(\mathrm{PPh}_{3}\right)\left\{\mathrm{P}\left(p-\mathrm{C}_{6} \mathrm{H}_{4} \mathrm{CF}_{3}\right)_{3}\right\}\right]$ and $\left[\mathrm{RuCl}(\right.$ ind $\left.)\left(\mathrm{PPh}_{3}\right)\left\{\mathrm{P}\left(3,5-\mathrm{C}_{6} \mathrm{H}_{3}\left(\mathrm{CF}_{3}\right)_{2}\right)_{3}\right\}\right]$ and all catalysis products] can be found at $\mathrm{xxx}$.

\section{Acknowledgments}

We would like to thank the National Science Foundation (NSF CHE-1300818, EBB; CHE-156509, MJS) for financial support. Further funding from the National Science Foundation for the purchase of the NMR spectrometer (CHE-9974801), the ApexII diffractometer (MRI, CHE-0420497), and the mass spectrometer (CHE-9708640) is acknowledged.

\section{References}

[1] (a) I. Dragutan, V. Dragutan, A. Demonceau, Molecules 20 (2015)17244-17274; (b)

P. Kumar, R. Kumar Gupta, D. Shankar Pandey, Chem. Soc. Rev. 43 (2014) 707-733; (c) F.

Nicks, Y. Borguet, S. Delfosse, D. Bicchielli, L. Delaude, X. Sauvage, A. Demonceau, Aust. J. Chem. 62 (2009) 184-207; (d) C. Bonaccorsi, A. Mezzetti, Curr. Org. Chem. 10 (2006) 225240; (e) K. Grela, A. Michrowska, M. Bieniek, The Chemical Record 6 (2006) 144-156; f) H. Schaffrath, W. Keim, J. Mol. Catal. A 168 (2001) 9-14.

[2] S.-I. Murahashi, D. Zhang, Chem. Soc. Rev. 37 (2008) 1490-1501.

[3] (a) D. J. Nelson, S. Manzini, C. A. Urbina-Blanco, S. P. Nolan, Chem. Commun. 50 (2014) 10355-10375; (b) Y. Vidavsky, A. Anaby, N. G. Lemcoff, Dalton Trans. 41 (2012) 3243; (c) K. Bieger, J. Díez, M. Pilar Gamasa, J. Gimeno, M. Pavlišta, Y. Rodríguez-Álvarez, S. García-Granda, R. Santiago-García, Eur. J. Inorg. Chem. (2002) 1647-1656; (d) R. H. Grubbs, Tetrahedron 60 (2004) 7117-7140. 
[4] (a) J. Francos, S. E. García-Garrido, J. García-Álvarez, P. Crochet, J. Gimeno, V. Cadierno, Inorg. Chim. Acta 455 (2017) 398-414; (b) C. Chen, F. Verpoort, Q. Wu, RSC Adv. 6 (2016) 55599-55607; (c) J. M. Sears, W.-C. Lee, B. J. Frost Inorg. Chim. Acta 431 (2015) 248257; (d) V. S. Thirunavukkarasu, S. I. Kozhushkov, L. Ackermann, Chem. Commun. 50 (2014) 29-39; (e) P. Crochet, V. Cadierno, Top. Organomet. Chem. 48 (2014) 48: 81-118; (f) J. Moran, M. J. Krische, Pure Appl. Chem. 84 (2012) 1729-1739.

[5] (a) A. A. Nazarov, C. G. Hartinger, P. J. Dyson, J. Organomet. Chem. 751 (2014) 251-260; (b) M. I. Webb, B. Wu, T. Jang, R. A. Chard, E. W. Y. Wong, M. Q. Wong, D. T. T. Yapp, C. J. Walsby, Chem. Eur. J. 19 (2013) 17031-17042; (c) O. Mazuryk, K. Kurpiewska, K. Lewiński, G. Stochel, M. Brindell, J. Inorg. Biochem. 116 (2012) 11-18; (d) N. P. E. Barry, P. J. Sadler, Chem. Soc. Rev. 41 (2012) 3264-3279; (e) Y. K. Yan, M. Melchart, A. Habtemariam, P. J. Sadler, Chem. Commun. (2005) 4764-4776.

[6] (a) J. M. Cole, K. Y. M. Yeung, G. Pace, S. O. Sylvester, D. Mersch, R. H. Friend, CrystEngComm 17 (2015) 5026-5031; (b) A. Breivogel, C. Kreitner, K. Heinze, Eur. J. Inorg. Chem. (2014) 5468-5490; (c) S. Fantacci, F. De Angelis, Coord. Chem. Rev. 255 (2011) 27042726.

[7] L. A. Oro, M. A. Ciriano, M. Campo, C. Foces-Foces, F. H. J. Cano, J. Organomet. Chem. 289 (1985) 117-131.

[8] (a) K. M. E. Burton, D. A. Pantazis, R. G. Belli, R. McDonald, L. Rosenberg, Organometallics 35 (2016) 3970-3980; (b) V. Cadierno, J. Díez, M. Pilar Gamasa, J. Gimeno, E. Lastra, Coord. Chem. Rev. 193-195 (1999) 147-205; (c) M. Pilar Gamasa, J. Gimeno, C. 
Gonzalez-Bernardo, B. M. Martín-Vaca, D. Monti, M. Bassetti, Organometallics 15 (1996) 302308.

[9] Examples: (a) I. García de la Arada, J. Díez, M. Pilar Gamasa, E. Lastra Organometallics 34 (2015) 1345-1353; (b) I. García de la Arada, J. Díez, M.P. Gamasa, E. Lastra J. Organomet. Chem. 797 (2015) 101-109.

[10] (a) S. Nolan, Acc. Chem. Res. 47 (2014) 3089-3101; (b) C. A. Mebi, R. P. Nair, B. J. Frost, Organometallics 26 (2007) 429-438; (c) K. Bieger, J. Díez, M. Pilar Gamasa, J. Gimeno, M. Pavlišta, Y. Rodríguez-Álvarez, S. García-Granda, R. Santiago-García, Eur. J. Inorg. Chem. (2002) 1647-1656; (d) P. Alvarez, J. Gimeno, E. Lastra, S. García-Granda, J. F. Van der Maelen, M. Bassetti, Organometallics 20 (2001) 3762-3771; (e) E. P. Kündig, C. M. Saudan, V.Alezra, F. Viton, G. Bernardinelli, Angew. Chem. Int. Ed. 40 (2001) 4481-4485; (f) M. Bassetti, S. Marini, F. Tortorella, V. Cadierno, J. Díez, M. Pilar Gamasa, J. Gimeno, J. Organomet. Chem. 593-594 (2000) 292-298; (g) Y. Yamamoto, H. Kitahara, R. Hattori, K. Itoh, Organometallics 17 (1998) 1910-1912.

[11] (a) M. José Calhorda, L. F. Veiros, Dalton Trans. 40 (2011) 11138-11146; (b) M. José Calhorda, C. C. Romão, L. F. Veiros, Chem. Eur. J. 8 (2002) 868-875; (c) L. F. Veiros, Organometallics 19 (2000) 3127-3136; (d) J. M. O’Connor, C. P. Casey, Chem. Rev. 87 (1987) 307-318; (e) J. W. Faller, R. H. Crabtree, A. Habib, Organometallics 4 (1985) 929-935.

[12] (a) M. J. Stark, M. J. Shaw, N. P. Rath, E. B. Bauer, Eur. J. Inorg. Chem. (2016) 1093-1102; (b) M. J. Queensen, J. M. Rabus, E. B. Bauer, J. Mol. Cat. A: Chem. 407 (2015) 221-229; (c) M. J. Queensen, N. P. Rath, E. B. Bauer, Organometallics 33 (2014) 5052-5065;

(d) D. F. Alkhaleeli, K. J. Baum, J. M. Rabus, E. B. Bauer, Catal. Commun. 47 (2014) 45-48; (e) 
A. K. Widaman, N. P. Rath, E. B. Bauer, New J. Chem. 35 (2011) 2427-2434; (f) S. Costin, A. K. Widaman, N. P. Rath, E. B. Bauer, Eur. J. Inorg. Chem. (2011) 1269-1282; (g) S. Costin, N. P. Rath, E. B. Bauer, Tetrahedron Lett. 50 (2009) 5485-5488; (h) S. Costin, S. L. Sedinkin, E. B. Bauer, Tetrahedron Lett. 50 (2009) 922-925; (i) S. Costin, N. P. Rath, E. B. Bauer, Adv. Synth. Catal. 350 (2008) 2414-2424.

[13] Representative examples: (a) O. bin Shawkataly, M. A. A. Pankhi, M. G. Alam, C. S. Yeap, H.-K. Fun, Polyhedron 30 (2011) 444-450; (b) R. Corrêa da Costa, F. Hampel, J. A. Gladysz, Polyhedron 26 (2007) 581-588.

[14] (a) A. C. Marr, M. Nieuwenhuyzen, C. L. Pollock, G. C. Saunders, Organometallics 26 (2007) 2659-2671; (b) F. Zhao, Y. Ikushima, M. Chatterjee, O. Sato, M. Arai, J. Supercrit. Fluids 27 (2003) 65-72.

[15] A. K. Renfrew, R. Scopelliti, P. J. Dyson, Inorg. Chem. 49 (2010) 2239-2246.

[16] D. Gudmunsen, E. G. Hope, D. R. Paige, A. M. Stuart J. Fluorine Chemistry 130 (2009) 942-950.

[17] R. Tuba, R. Corrêa da Costa, H. S. Bazzi, J. A. Gladysz, ACS Catal. 2 (2012) $155-162$.

[18] S. Costin, N. P. Rath, E. B. Bauer Inorg. Chem. Commun. 14 (2011) 478-480.

[19] E. J. Derrah, J. C. Marlinga, D. Mitra, D. M. Friesen, S. A. Hall, R. McDonald, L. Rosenberg, Organometallics 24 (2005) 5817-5827.

[20] M. Kamigaito, Y. Watanabe, T. Ando, M. Sawamoto, J. Am. Chem. Soc. 124 (2002) 9994-9995. 
[21] (a) C. R. Martinez, B. L. Iverson, Chem. Sci. 3 (2012) 2191-2201; (b) C. Janiak J.

Chem. Soc., Dalton Trans. (2000) 3885- 3896.

[22] (a) J. Lodinský, J. Vinklárek, L. Dostál, Z. Růžičková, J. Honzíček, RSC Adv. 5 (2015) 27140-27153; (b) J. Honzíček, J. Vinklárek, M. Erben, J. Lodinský, L. Dostál, Z. Padělkova, Organometallics 32 (2013) 3502-3511.

[23] S. Costin, N. P. Rath, E. B. Bauer, Inorg. Chim. Acta 362 (2009) 1935-1942.

[24] (a) B. Suthar, A. Aldongarov, I. S. Irgibaeva, M. Moazzen, B. T. Donovan-Merkert, J. W. Merkert, T. A. Schmedake, Polyhedron 31 (2012) 754-758; (b) A. P. Shaw, J. R. Norton, D. Buccella, L. A. Sites, S. S. Kleinbach, D. A. Jarem, K. M. Bocage, C. Nataro, Organometallics 28 (2009) 3804-3814; (c) A. R. O’Connor, C. Nataro, A. L. Rheingold, J. Organomet. Chem. 679 (2003) 72-78; (d) S. Santi, L. Broccardo, M. Bassetti, P. Alvarez, Organometallics 22 (2003) 3478-3484.

[25] General examples and reviews regarding the nucleophilic substitution of propargylic alcohols: (a) K, Nakajima, M. Shibata, Y. Nishibayashi J. Am. Chem. Soc. 137 (2015) 2472-2475; (b) D.-Y. Zhang, X.-P. Hu, Tetrahedron Lett. 56 (2015) 283-295; (c) B. Wang, C. Liu, H. Guo, RSC Adv. 4 (2014) 53216-53219; (d) F.-Z. Han, F.-L. Zhu, Y.-H. Wang, Y. Zou, X.-H. Hu, S. Chen, X.-P. Hu, Org. Lett. 16 (2014) 588-591; (e) Eike B. Bauer, Synthesis 44 (2012) 1131-1151; (f) Y. Nishibayashi, Synthesis 44 (2012) 489-503; (g) R. J. Detz, H. Hiemstra, J. H. van Maarseveen, Eur. J. Org. Chem. (2009) 6263-6276; (h) N. Ljungdahl, N. Kann, Angew. Chem. Int. Ed. 48 (2009) 642-644.

[26] (a) B. Schmidt, Eur. J. Org. Chem. (2004) 1865-1880; (b) M. B. Dinger, J. C. Mol, Organometallics 22 (2003) 1089-1095. 
[27] (a) A. B. P. Lever, Coord. Chem. Rev. 254 (2010) 1397-1405; (b) C. Slugovc, E. Rüba, R. Schmid, K. Kirchner, K. Mereiter, Monatsh. Chem. 131 (2000) 1241-1251.

[28] S. S. Keisham, Y. A. Mozharivskyj, P. J. Carroll, M. R. Kollipara, J. Organomet. Chem. 689 (2004) 1249-1256.

[29] Representative examples: (a) S. L. Kuan, W. K. Leong, R. D. Webster, L. Y. Goh, Organometallics 31 (2012) 5159-5168; (b) A. Yoshinari, A. Tazawa, S. Kuwata, T. Ikariya, Chem. Asian J. 7 (2012) 1417-1425; (c) W. M. Khairul, M. A. Fox, N. N. Zaitseva, M. Gaudio, D. S. Yufit, B. W. Skelton, A. H. White, J. A. K. Howard, M. I. Bruce, P. J. Low, Dalton Trans. (2009) 610-620; (d) S. Nagao, H. Seino, M. Hidai, Y. Mizobe, Dalton Trans. (2005) 3166-3172; (e) J. Matthes, S. Gründemann, A. Toner, Y.

Guari, B. Donnadieu, J. Spandl, S. Sabo-Etienne, E. Clot, H.-H. Limbach, B. Chaudret, Organometallics 23 (2004) 1424-1433.

[30] J. S. Valentine, Chem. Rev. 73 (1973) 235-245.

[31] (a) T. T. da Cunha, F. Pointillart, B. Le Guennic, C. L. M. Pereira, S. Golhen, O. Cador, L. Ouahab, Inorg. Chem. 52 (2013) 9711-9713; (b) L. Terborg, S. Nowak, S. Passerini, M. Winter, U. Karst, P. R. Haddad, P. N. Nesterenko, Anal. Chim. Acta 714 (2012) 121- 126;

(c) N. R. Brooks, A. J. Blake, N. R. Champness, J. W. Cunningham, P. Hubberstey, M. Schröder, Cryst. Growth Des. 1 (2001) 395-399; (d) M. Di Vaira, M. Peruzzini, S. S. Costantini, P. Stoppioni, J. Organomet. Chem. 691 (2006) 3931-3937.

[32] F. Barrière, W. E. Geiger, J. Am. Chem. Soc. 128 (2006) 3980-3989.

[33] Bruker Analytical X-Ray, Madison, WI, 2016

[34] G. M. Sheldrick, Acta Cryst. A64 (2008)112-122. 
[35] S. Parsons, H. Flack, Acta Cryst. A60 (2004) s61.

[36] A. L. Spek, Acta Cryst. A46 (1990) C34. 